\title{
The Dark Side of Platinum Based Cytostatic Drugs: From Detection to Removal
}

\author{
Yessica Roque-Diaz ${ }^{1}$ (D), Martina Sanadar ${ }^{2}$ (D), Dong Han ${ }^{3}$ (D), Montserrat López-Mesas ${ }^{3}$, Manuel Valiente ${ }^{3}$, \\ Marilena Tolazzi ${ }^{2}$, Andrea Melchior ${ }^{2, *(D)}$ and Daniele Veclani 2,4,*
}

1 CIDEM, Centro de Investigación y Desarrollo de Medicamentos, Plaza de la Revolución, La Habana 10600, Cuba; yessica.roque957@gmail.com

2 Dipartimento Politecnico di Ingegneria e Architettura, Laboratori di Chimica, Università di Udine, Via del Cotonificio 108, 33100 Udine, Italy; sanadar.martina@spes.uniud.it (M.S.); marilena.tolazzi@uniud.it (M.T.)

3 GTS-UAB Research Group, Department of Chemistry, Faculty of Science, Universitat Autònoma de Barcelona, Bellaterra, (Cerdanyola del Vallès), 08193 Barcelona, Spain; Dong.Han@uab.cat (D.H.); montserrat.lopez.mesas@uab.cat (M.L.-M.); Manuel.Valiente@uab.cat (M.V.)

4 Institute of Organic Synthesis and Photoreactivity (ISOF), National Research Council of Italy (CNR) Area della Ricerca di Bologna, Via Gobetti 101, 40129 Bologna, Italy

* Correspondence: andrea.melchior@uniud.it (A.M.); daniele.veclani@isof.cnr.it (D.V.)

Citation: Roque-Diaz, Y.; Sanadar, M.; Han, D.; López-Mesas, M.; Valiente, M.; Tolazzi, M.; Melchior, A.; Veclani, D. The Dark Side of Platinum Based Cytostatic Drugs: From Detection to Removal. Processes 2021, 9, 1873. https://doi.org/10.3390/ pr9111873

Academic Editor: Marco S. Lucas

Received: 2 August 2021

Accepted: 16 October 2021

Published: 21 October 2021

Publisher's Note: MDPI stays neutral with regard to jurisdictional claims in published maps and institutional affiliations.

Copyright: (c) 2021 by the authors. Licensee MDPI, Basel, Switzerland. This article is an open access article distributed under the terms and conditions of the Creative Commons Attribution (CC BY) license (https:/ / creativecommons.org/licenses/by/ $4.0 /)$.

\begin{abstract}
The uncontrolled release of pharmaceutical drugs into the environment raised serious concerns in the last decades as they can potentially exert adverse effects on living organisms even at the low concentrations at which they are typically found. Among them, platinum based cytostatic drugs (Pt CDs) are among the most used drugs in cancer treatments which are administered via intravenous infusion and released partially intact or as transformation products. In this review, the studies on environmental occurrence, transformation, potential ecotoxicity, and possible treatment for the removal of platinum cytostatic compounds are revised. The analysis of the literature highlighted the generally low total platinum concentration values (from a few tens of $\mathrm{ng} \mathrm{L}^{-1}$ to a few hundred $\mu \mathrm{g} \mathrm{L}^{-1}$ ) found in hospital effluents. Additionally, several studies highlighted how hospitals are sources of a minor fraction of the total $\mathrm{Pt} C D$ s found in the environment due to the slow excretion rate which is longer than the usual treatment durations. Only some data about the impact of the exposure to low levels of Pt CDs on the health of flora and fauna are present in literature. In some cases, adverse effects have been shown to occur in living organisms, even at low concentrations. Further ecotoxicity data are needed to support or exclude their chronic effects on the ecosystem. Finally, fundamental understanding is required on the platinum drugs removal by MBR, AOPs, technologies, and adsorption.
\end{abstract}

Keywords: cytostatic drugs; water treatment; environmental remediation; emerging pollutants

\section{Introduction}

Cancer, considered the second cause of death in the world, is a primary global public health issue [1]. The International Agency for Research on Cancer (IARC) estimates that by $2040,30.2$ million new cases of cancer will be diagnosed worldwide, with more than 16 million expected deaths [2]. The increment in cancer frequency will consequently be associated with an increase in the use of cytostatic drugs (CDs) to treat this disease [3]. CDs are cytotoxic molecules designed and applied to cause cellular dysfunction. These compounds inhibit the growth of cancer cells by altering their metabolism, blocking cell division and reproduction [4]. Despite all the advantages, cytostatic damage is not exclusively specific to tumor cells, but has an impact on all body cells, causing adverse side effects such as renal, digestive, hematopoietic, liver, and dermal [4]. Once administered, these compounds are excreted from the body unchanged or as metabolites that pass into the effluents of hospitals and homes, until they arrive in the sewage system and so the wastewater treatment plant (WWTP) [3]. The removal efficiency in the WWTP depends on 
the treatment process and the substance, but in general CDs are poorly biodegradable and are released into the terrestrial and aquatic systems contaminating rivers, and even into the sea, at trace levels [5]. Another source to be considered is the effluents from pharmaceutical manufacturing plants that have been unrestrictedly discharged into the environment [6-9].

These water bodies contaminated by CDs, in many cases, can harm the lives of humans and other aquatic organisms exposed to them, causing long-term damage to those eukaryotic organisms, even at trace level. For this reason, the EU Commission Decision 2000/532/EC251 classified the cytotoxic and cytostatic medicinal products as hazardous wastes [10].

Platinum-based CD are the most employed drugs in cancer treatments, and it is estimated that their usage will continue to increase in the next years. Cisplatin is the most relevant anticancer drug ever discovered, and as of today about $50 \%$ of all cancer patients are cured with this metal drug [11]. Over the last 30 years numerous platinum compounds were tested [12-15], but only a few obtained international marketing approval: carboplatin, oxaliplatin, nedaplatin, heptaplatin, and lobaplatin (Figure 1) [14].


heptaplatin

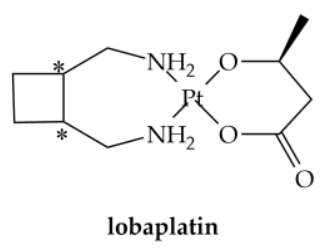

Figure 1. Clinically approved platinum anticancer drugs. *: chiral centres.

Studies addressing their occurrence in different environments, as well as the proper elimination or degradation methods from the wastewaters (WW), are numerous [6,16-19]. Despite their concentrations, hospital wastewaters (HWW), sewage, and natural waters are very low (typically in the $\mathrm{ng} \mathrm{L}^{-1}$ range or lower) $[6,20]$. Numerous studies have measured the cytostatic concentrations in surface waters. Most of these studies have reported that, in general, these drug residues are safe for the aquatic biota, with few exceptions [21,22].

The presence of cisplatin and cisplatin-based cytostatics has been found to display an apparently low environmental risk [23]; however, recent evidence suggests that predictions of cytostatic concentrations in the water bodies have been underestimated [24].

This evidence, together with the expected increase of the use of cytostatics in the coming years and the lack of research on potential chronic damage [25], could put the health of entire ecosystems at risk.

Therefore, it is important to develop efficient methods for removing these compounds from WW. Based on an intensive literature review, this work aims to summarize and discuss: (i) the mechanism of action of Pt-based CDs, their source and determinations; (ii) the predicted behavior in the aquatic and related environments; (iii) the ecotoxicological potential; and (iv) the impact of water treatment technologies. 


\section{Action Mechanism, Speciation and Determinations Analysis of Pt-Based CDs \\ 2.1. Reactivity}

Since Rosenberg and co-workers $[26,27]$ unexpectedly discovered the antiproliferative action of the cis-diamminedichloroplatinum(II) $\left(\mathrm{Pt}\left(\mathrm{NH}_{3}\right)_{2} \mathrm{Cl}_{2}\right)$ (Figure 1), cisplatin, many studies have been carried out to develop compounds with less severe side effects and improved efficacy $[14,15,28]$.

Experimental evidence revealed that the mechanism of action (Figure 2) of classical platinum CDs is characterized by four steps process: (1) cellular uptake, (2) activation by the chloride substitution reactions, (3) DNA binding, and (4) cellular processing of DNA lesions leading to cell death [28].

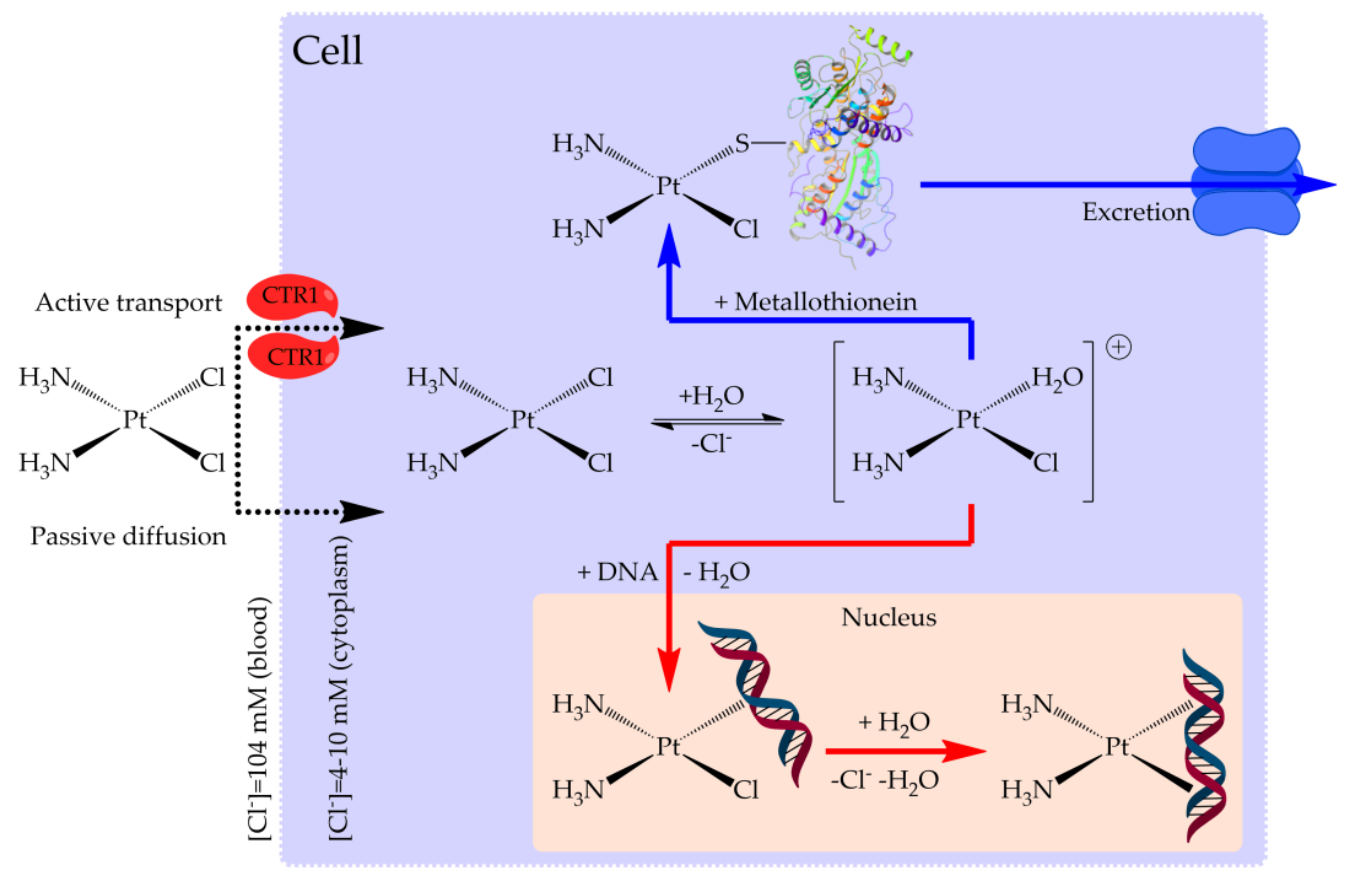

Figure 2. Mechanism of action of cisplatin.

Passive diffusion and active transport, facilitated by membrane proteins, are both involved in cellular uptake [29]. In the blood stream, where the chloride concentration is relatively high, the chloride release is suppressed, while, in the cell, they are replaced by water in solution to produce positively charged "aquated" molecules (Figure 3) [30]. These aqua-complexes (and in particular $\mathrm{Pt}\left(\mathrm{NH}_{3}\right)_{2}\left(\mathrm{OH}_{2}\right) \mathrm{Cl}^{+}$) are very reactive and can form covalent bonds with DNA bases. Numerous experimental and theoretical studies were devoted to clarify these reactions [31-40].

The final cisplatin-DNA adducts present coordinated intra- and inter-strand crosslinks which activate a series of processes ultimately leading to cell death. It is interesting to note that these reactive aqua-derivatives of cisplatin are also detected in the urine with a speciation dependent on the temperature, chloride concentration, and $\mathrm{pH}$ (Figure 3) [41].

Carboplatin or cis-diammine-(1,1-cyclobutanecarboxylato)platinum(II) (Figure 1) is an antineoplastic drug widely used against cancer of head, neck, lung, and ovaries [42,43]. Carboplatin is an early example of attempt to develop less toxic platinum alkylating agents, and was introduced in clinical use in the mid-1980s [44]. The principal chemical structure difference between carboplatin and cisplatin was the presence of bidentate dicarboxylate (CBDCA) ligand instead of the two chloride ligands of cisplatin molecule [12]. It shows lower reactivity and slower DNA binding kinetics [12] which makes it less toxic than cisplatin [45]. Oxaliplatin (trans-L-diaminocyclohexane oxalatoplatinum(II), Figure 1) emerged as the prominent third-generation platinum based anticancer drugs [46]. In the late 1970s, oxaliplatin was suggested as a possible anticancer drug but the FDA approval 
was obtained only in 2002 [46]. It was employed in the treatment of several kinds of cancers, including colon cancer, which had not responded to cisplatin treatment [46], gastrointestinal, and gynecologic cancers [47]. It is interesting to note that carboplatin and oxaliplatin present a quite different chemical reactivity profile, which affects the speciation in excreted samples (urine): in the first case the intact drug is excreted, while for oxaliplatin up to 17 metabolites were determined [48].

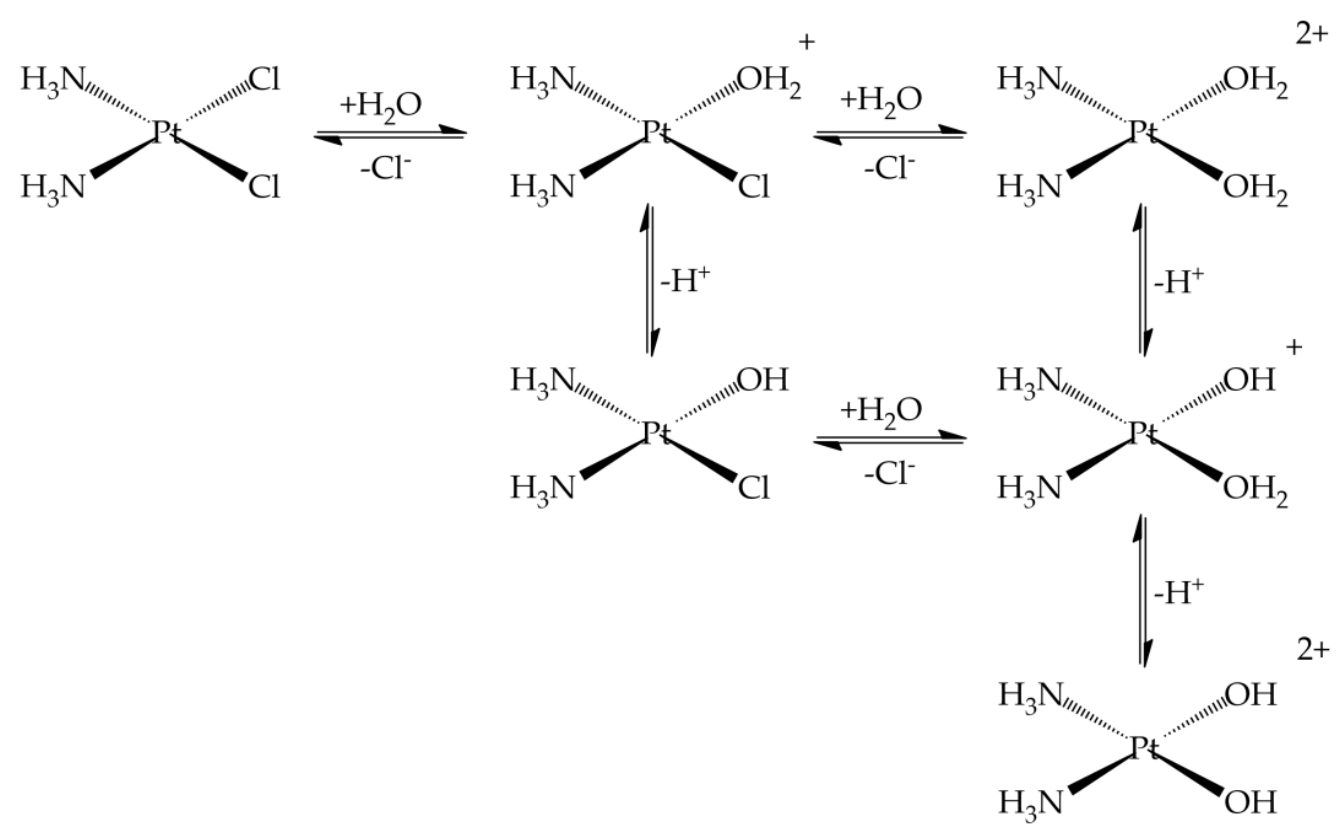

Figure 3. Ligand substitution (chloride) and protonation equilibria for cisplatin.

Nedaplatin, heptaplatin, and lobaplatin (Figure 1) are approved only in some countries (Japan, Korea, and China respectively) [29].

\subsection{Prediction of Platinum-Based CDs Release into the Environment}

The evacuation of urine and feces from patients treated with anticancer agent is regarded as the primary source of platinum-based anticancer drugs and their related metabolites. These compounds have been unrestrictedly discharged into the environment, via hospital effluents and/or municipal WW, and possibly also effluents from pharmaceutical manufacturing plants [9,48-52]. In Figure 4 the routes of platinum-based anticancer drug input and transportation in the environment are shown.

As early as more than 20 years ago, researchers have been keenly aware that Ptcontaining pharmaceutical residues frequently appeared in HWW. The calculation of the PEC (predicted environmental concentrations) of platinum-based cytostatic compounds, as well as their quantification through total Pt determination methods [48,53-55] are the methods employed to predict and determine the environmental occurrence of these compounds.

In one interesting study [17] it was attempted to predict the possible concentrations range of four cytostatics in the sewage effluent and surface waters of various states in the European Union: 5-fluorouracil (5FU), capecitabine (CB), cyclophosphamide (CP), and carboplatin. The prediction of the range of cytostatics concentrations was made by using literature data on human excretion values, publicly available consumption data, and sewage removal rates of every country. The results predicted mean effluent concentrations of carboplatin were $0.8-2.5 \mathrm{ng} \mathrm{L}^{-1}$, which are similar to 5-FU, and lower than $\mathrm{CP}$ and $\mathrm{CB}$. Several studies have estimated the environmental concentrations of platinum-based CDs through the calculation of the PEC [9,16,56]. The PECs [57] of cisplatin, carboplatin, and oxaliplatin established on their consumption for the years 2004 and 2008 in France were determined. Interestingly, an increase in the PECs of the three drugs was observed in the 
year 2008 with respect to the year 2004 (Table 1). However, the same study [57] concluded that hospital effluents are not the principal source of anticancer drugs into the aquatic environment as also observed in ref. [54].



Figure 4. Routes through which platinum-based anticancer drugs are input and transported in the environment.

Table 1. Predicted PEC concentrations $\left(\mathrm{ng} \mathrm{L}^{-1}\right)$ of carboplatin, oxaliplatin, and cisplatin in France, in the years 2004 and 2008 [57].

\begin{tabular}{lll}
\hline CD & $\mathbf{2 0 0 4}$ & $\mathbf{2 0 0 8}$ \\
\hline carboplatin & 1.47 & 1.91 \\
\hline oxaliplatin & 0.46 & 0.76 \\
\hline cisplatin & 0.40 & 0.52 \\
\hline
\end{tabular}

In ref. [56] a PEC and analytical study on HWW of the city of Qom indicated a Pt concentration lower than that of the EMEA guidelines and that the investigation and monitoring of the residual of cytotoxic anticancer drugs should be taken into account considering the low efficiency of conventional WWTP in removing platinum cytotoxic pharmaceutical compounds.

One point which has to be taken into account when considering data on platinum CDs occurrence is that the CDs-derived metal found in the environment is $1-2$ orders of magnitudes lower than other manufacturing/industrial sources [58].

A recent risk assessment study has been conducted in Brazil [59] on several CDs which indicated that the highest PEC was associated with $\mathrm{CP}, 5-\mathrm{FU}$, and cytarabine while for cisplatin and carboplatin the value was significantly lower. However, authors underline the fact that the analysis was conducted in an urban area with a WWTP and that other, less developed, areas could have higher concentrations.

\subsection{Analytical Techniques}

Given the low concentrations involved in the analysis of biological and environmental samples, different techniques have been developed in recent years to try to decrease the limit of detection (LOD) of Pt-CDs in biological (urine, plasma) and especially environmental samples where the dilution factor is higher [60]. Additionally, it emerged that speciation is important to determine the amounts of intact drug and transformation products. In 
order to obtain these objectives, liquid chromatography protocols (mostly coupled with MS detection) or electroanalytical sensors have been developed in the last decades.

\subsubsection{Biological Samples}

High Performance Liquid Chromatography (HPLC) analysis of antitumor Pt-CDs based on UV-Vis detection exploiting the reaction of $\mathrm{Pt}$ complexes with sodium bisulfite to enhance the absorptivity was realized to detect cisplatin, carboplatin, and oxaliplatin in plasma and urine [61]. LOD for cisplatin, oxaliplatin, and carboplatin were 20, 40, and $60 \mathrm{nM}$, respectively.

An HPLC method was also proposed for cisplatin analysis in ultrafiltrate plasma in the presence of nickel chloride as internal standard. Cisplatin and the internal standard were chelated by exchange with diethyldithiocarbamate (DDTC) for UV-Vis detection. The limit of quantification was $0.03 \mu \mathrm{g} \mathrm{mL} \mathrm{m}^{-1}$ using only $0.5 \mathrm{~mL}$ of ultrafiltrate.

In another work, HPLC coupled with UV-Vis detection (direct or with post-column bisulfite derivatization) was also used for the quantitation of carboplatin in human plasma ultrafiltrate provided a LOD of $0.025 \mu \mathrm{g} \mathrm{mL}^{-1}$. After validation, this method was used to study the pharmacokinetic analysis of blood samples drawn from a patient that received a $400 \mathrm{mg} \mathrm{m}^{-2}$ dose of carboplatin [62].

Fast oxaliplatin determination in urine was developed by Hann et al. with an LOD of $0.05 \mu \mathrm{g} \mathrm{L}^{-1}$ oxaliplatin [63]. In this case, it was found that samples needed to be rapidly stored at $-80^{\circ} \mathrm{C}$ to detect the intact drug.

Carboplatin was measured in urine of a chemotherapy patient by using IDMS (isotope dilution mass spectrometry) technique both with LC-ICP-QMS (HPLC coupled with inductively coupled plasma source and elemental quadrupole based mass spectrometer) and LC-ESI-TOFMS (HPLC with a electrospray ionization source and time-of-flight MS) [64]. The procedural LOD for the two techniques were 0.1 and $15 \mathrm{ng} \mathrm{g}^{-1}$ respectively. However, it should be noted that ${ }^{194} \mathrm{Pt}$-enriched compound has to be prepared.

HPLC coupled with tandem mass spectrometry detection (HPLC-ESI-MS/MS) has been also used for the quantitative determination of Pt after derivatizing with DDTC [65]. The quantification was obtained using a triple quadrupole with electrospray ionization and detection was achieved using multiple reaction monitoring. The authors reported a LOD of $1 \mathrm{ng} \mathrm{mL} \mathrm{m}^{-1}$, and the quantifiable range was 3-3000 $\mathrm{ng} \mathrm{mL}^{-1}$ in urine and rat plasma [65].

Atomic absorption spectrometry (AAS) was employed to determine cisplatin and carboplatin in human urine [66]. Samples from healthy individuals not subjected to treatment with platinum drugs were collected in polypropylene tubes $(50 \mathrm{~mL})$ and stored at $4{ }^{\circ} \mathrm{C}$ until analysis. Urine samples from a treated patient collected within $48 \mathrm{~h}$ was collected and stored at $-4{ }^{\circ} \mathrm{C}$. The obtained LOD resulted $0.004 \mathrm{mg} \mathrm{L}^{-1}$ of platinum.

Conjoint liquid chromatography (CLC) coupled on-line to UV and ICP-MS was employed for the speciation analysis of $\mathrm{Pt}$ in human serum spiked with cisplatin, oxaliplatin, and carboplatin [67]. The limit of quantitation (LOQ) was lower than $2.4 \mathrm{ng} \mathrm{Pt} \mathrm{mL} \mathrm{PL}^{-1}$. This method allowed for study the interaction of Pt-CDs with serum proteins and showed they were bound preferentially to human serum albumin (HSA).

A validated ICP-MS method for quantitative determination of platinum levels in rat urine, plasma, and tissues (rat liver, brain, lungs, kidney, muscle, heart, spleen, bladder, and lymph nodes) was also proposed [68] with a limit of quantitation of $5 \mathrm{ppb}$. In that case, the samples were treated by microwave digestion.

Two non-suppressed ion chromatography (IC) methods, one with an anion and one with a cation separation column, were used for determinations of cisplatin and carboplatin [69]. In this study, an inductively coupled plasma-atomic emission spectrometry (ICP-AES) was used as detector and the obtained LOD was $0.1 \mathrm{mg} \mathrm{L}^{-1}$ for both Pt-CDs.

A high throughput analytical method based on ICP-MS for the determination of total Pt in plasma, plasma ultrafiltrate, urine, and peritoneal fluid was proposed [70]. The claimed advantage of this protocol resides in the high sensitivity (LOD $=1.76 \mathrm{ng} \mathrm{mL}^{-1}$ 
Pt in plasma, $0.39 \mathrm{ng} \mathrm{mL}^{-1}$ in ultrafiltrate, $0.29 \mathrm{ng} \mathrm{mL}^{-1}$ in urine, and $0.30 \mathrm{ng} \mathrm{mL}^{-1}$ in peritoneal fluid) and fast and simple sample preparation.

Folens et al. [71] determined the release of platinum in the urine of patients by means of ICP-MS to obtain a pharmacokinetic model which suggested that retaining the Pt in the first $24 \mathrm{~h}$ after the treatment would be convenient for the recovery, as after the concentrations are very small (see also Section 5). For the analytical part they collected urine samples, which were subjected to a microwave digestion step followed by ICP-MS analysis with a LOD of $0.005 \mu \mathrm{g} \mathrm{L}^{-1}$.

As far as electroanalytical methods are concerned, several works have been made, mostly with the objective to develop sensitive sensors for fast analyses on biological and/or environmental samples.

An electrochemical cisplatin and carboplatin specific sensor was made with a thiolated and methylene blue-modified oligo-adenine (A)-guanine (G) DNA probe [72]. The obtained LOD was $500 \mathrm{nM}$, with linearity between 0.5 and $5 \mu \mathrm{M}$. This sensor was tested on simulated urine and saliva samples and, interestingly, it was insensitive to Pt(IV) compound or commonly prescribed antibiotics.

In 2006 Petrlova and coworkers developed a sensor for cisplatin by modifying a mercury drop electrode with metallothionine, a protein that reacts readily with platinum complexes [73]. Both modifications of the electrode and the identification of cisplatin were obtained by adsorptive transfer stripping technique and differential pulse voltammetry applied to the analysis of cisplatin in human blood serum. Results showed that the LOD was about $2.5 \mathrm{pmol}$ in $5 \mu \mathrm{L}(0.5 \mu \mathrm{M})$ with an interaction time of $400 \mathrm{~s}$; this limit was calculated from the decrease of the highest observed signal (CdT) peak.

Carbon-based nanomaterials (CNM), such as carbon nanotubes (CNTs) and graphene, played a great role in the electronic and sensor field thanks to their peculiar proprieties $[32,74,75]$. A graphene-based electrochemical sensor made by nano-porous glassy carbon electrode (npGCE) and modified with graphene quantum dots (GQDs) functionalized with thionine groups showed sensitive and selective determination of cisplatin [76]. The determinations of cisplatin in different fluids, such as urine and blood serum samples, were obtained by cyclic voltammetry. The results showed that the linear range was $0.2-110 \mu \mathrm{M}$ with the LOD of $90 \mathrm{nM}$. The authors stated that this was the lowest LOD obtained for cisplatin.

Another interesting sensor [77] for electrochemical determination of platinum complexes was obtained from the functionalization of screen printed electrodes with multiwalled carbon nanotubes and factory modified with carboxyl groups. The LOD and LOQ reported were 4.6 and $1.4 \mu \mathrm{mol} \mathrm{L}-1$. These results were further compared with those obtained by HPLC, and the average error \% (sensor/HPLC) was 3.4, indicating that the developed sensor was an appropriate alternative to the use of HPLC for cisplatin determination in biological samples.

Recently also a fluorescent sensor array has been used to detect platinum in clinical human blood samples [78]. These sensors were able also to distinguish between different compounds in the $0.5-5.0 \mu \mathrm{M}$ range.

\subsubsection{Environmental Samples}

One of the first articles where the presence of cisplatin and carboplatin in sewage of five European hospitals was determined by Kummerer et al. using adsorptive voltammetry technique [50]. Their results showed that $70 \%$ of the drugs were excreted and reached the hospital effluents. The hospital effluents average daily concentrations were approximately 10-601 ng L $\mathrm{L}^{-1}$ of $\mathrm{Pt}$; these data were then compared with an estimation of the Pt emitted by cars. The authors observed that Pt emitted by hospitals was 3.3 to $1.3 \%$ of the estimated amount emitted by cars, indicating that the effluents of hospitals have a limited influence on municipal WW; however, the Pt species emitted by hospital should not be disregarded [50].

In other works, the presence of the CDs as total Pt in the matrix under study (Table 2) was determined. In 2005, Lenz et al. [48] measured the excreted CPC in HWW sampled 
in Vienna in a period of 28 days. As a result, it was found that the Pt concentrations were ranging from 4.7-145 $\mu \mathrm{g} \mathrm{L}^{-1}$. Two years later, in 2007, the same group [79] measured the total $\mathrm{Pt}$ in the influents and effluents of a pilot membrane bioreactor (MBR) plant of the same hospital, and the concentrations oscillated from 3-250 $\mu \mathrm{g} \mathrm{L}^{-1}$ and 2-144 $\mu \mathrm{g} \mathrm{L}^{-1}$ in the influents and effluents, respectively. In this study, the consumption of Pt-CDs in the oncological ward was also recorded, and it was observed that (1) only the $27-34 \%$ of the administered $\mathrm{Pt}$ is found in the WW of the oncological ward; (2) around 51-64\% of platinum is removed in the activated sludge MBR.

Another study performed in a hospital in UK [54] reported Pt concentrations ranging from 20.02 to $140 \mu \mathrm{g} \mathrm{L}^{-1}$ in the effluents and hospital's main drain.

The presence of antitumor drugs in the hospital effluents and in WWTP influents and effluents form Slovenia and Spain and their metabolites was studied [55]. Cisplatin was determined as total Pt using ICP-MS (Table 2). In Slovenia the Pt concentrations in hospital effluents was around $352 \mathrm{ng} \mathrm{L}^{-1}$. The Pt concentrations in the WWTP influents were around $27 \mathrm{ng} \mathrm{L}^{-1}$, while the Pt concentrations in effluents were below the LOD. In contrast, all the samples taken in Spain had Pt concentrations below the LOD of the method employed. The hospitals under study were different in every region, in Slovenia; the sample collection was made from the oncological ward, while in Spain samples were collected at a general hospital. The general hospital from Spain was approximately 4-times bigger, which means that the concentration of the platinum drugs in the influents and effluents was highly diluted, which may be a reason why the method could not detect them.

When platinum-based anticancer drugs repeatedly appear in hospital sewage, municipal WW receive a considerable contribution of excreted antineoplastic compounds as the result of outpatient treatment [80]. It is worth noting that the increasing number of outpatients nowadays results in the fact that domestic discharge will become another important source of Pt contamination as also suggested in ref. [17,56].

Santana et al. also sampled from a WWTP of Gran Canarias Island (Spain) for the determination of cytostatic platinum compounds and found that concentrations in the range 1.94-13,913 $\mathrm{ng} \mathrm{L}^{-1}$ in HWW and 3.97 and $75.79 \mathrm{ng} \mathrm{L}^{-1}$ in WWTP by ICP-MS analysis. Authors presented an optimized method for the extraction and preconcentration of Pt-CDs in WW samples based on ion exchange solid phase extraction which allowed to reach a very low LOQ [81].

Data reported in Table 2 indicate that the lower LOD values were obtained by electroanalytical technique. To solve many fundamental and important problems with a high degree of accuracy, precision, sensitivity, selectivity, and reproducibility, electroanalytical techniques can be easily employed [82].

Several platinum complexes, such as cisplatin, carboplatin, oxaliplatin, $\mathrm{PtCl}_{4}{ }^{2-}$ and $\mathrm{PtCl}_{2}$, was also coupled with flow injection analysis with electrochemical detection (FIA-ED) method [83]. The flow injection instrument was made with a solvent delivery pump and an electrochemical detector consisting in a: (i) working electrode: glassy carbon electrode; (ii) reference: hydrogen-palladium electrode; (iii) auxiliary electrode. A sample of water from the Ponavka river, where platinum complexes were added in concentrations of 10 and $40 \mu \mathrm{g} \mathrm{mL}^{-1}$, was used as a reference solutions to verified this method. Interestingly, the proposed method could discriminate between the Pt-CDs and the chloride complexes.

The health risk assessment of platinum CDs in drinking water of Qom province in Iran has been evaluated [84]. HPLC-MS was employed for the quantification of the components. The results of this study showed cytostatics concentrations above $100 \mathrm{ng} \mathrm{L}^{-1}$ in every case and in the case of carboplatin above $900 \mathrm{ng} \mathrm{L}^{-1}$ in the WWTP influents.

Determinations of carboplatin and oxaliplatin in WW samples was carried out also by HPLC-MS/MS [85]. The LODs obtained for carboplatin and oxaliplatin were 0.013 and $0.090 \mathrm{ng} \mathrm{L}^{-1}$, while LOQ was 0.4 and $0.027 \mathrm{ng} \mathrm{L}^{-1}$, respectively. Recovery (\%) was 0.78 and 0.74 and the RSD\% was between 6.0 to $8.9 \%$ and 7.5 to $7.9 \%$ for carboplatin and oxaliplatin respectively, while the correlation coefficients were 0.9998 and 0.9990 . The environmental 
risk assessment was carried out and the risk quotients (RQ) obtained were 0.51 and 0.038 for carboplatin and oxaliplatin respectively, indicating that these compounds had low environmental exposure risk. $R Q$ value is the ratio between the predicted environmental concentration and the prognosticated no-effect concentration. A value of $R Q<1.0$ shows no significant risk; RQ between 1.0 and 10 indicates small possible adverse effects; a value higher than 10 indicates significant potential for adverse effects and value $\geq 100$ indicates that potential side effects can be predictable.

Table 2. Determination of Pt CDs in biological and environmental samples.

\begin{tabular}{|c|c|c|c|c|c|}
\hline \multicolumn{6}{|c|}{ Biological Samples } \\
\hline Compound & Method & Experimental Remarks & Sample & LOD & Ref. \\
\hline $\begin{array}{l}\text { cisplatin } \\
\text { carboplatin } \\
\text { oxaliplatin }\end{array}$ & HPLC/UV-Vis & $\begin{array}{l}\text { post-column derivatization with } \\
\text { sodium bisulfite }\end{array}$ & plasma, urine & $20-60 \mathrm{nM}$ & {$[61]$} \\
\hline $\begin{array}{l}\text { cisplatin } \\
\text { carboplatin } \\
\text { oxaliplatin }\end{array}$ & HPLC UV-Vis & Reaction with DDTC & plasma and urine & $20-60 \mathrm{nM}$ & {$[61]$} \\
\hline cisplatin & HPLC UV-Vis & Reaction with DDTC & ultrafiltrate plasma & $0.025 \mu \mathrm{g} / \mathrm{mL}$ & {$[62]$} \\
\hline oxaliplatin & HPLC-ICP-MS & $\begin{array}{l}\text { Samples collected and stored at } \\
\text { different temperatures }\end{array}$ & urine & $0.05 \mu \mathrm{g} \mathrm{L}^{-1}$ & {$[63]$} \\
\hline carboplatin & $\begin{array}{l}\text { LC-ICP-QMS } \\
\text { LC-ESI-TOFMS }\end{array}$ & $\begin{array}{l}{ }^{194} \mathrm{Pt} \text { enriched carboplatin for species } \\
\text { specific isotope dilution analysis }\end{array}$ & urine & $\begin{array}{l}1 \mathrm{ng} \mathrm{g}^{-1} \\
15 \mathrm{ng} \mathrm{g}^{-1}\end{array}$ & {$[64]$} \\
\hline $\begin{array}{l}\text { cisplatin } \\
\text { carboplatin }\end{array}$ & AAS & Samples collected and stored at $-4{ }^{\circ} \mathrm{C}$ & urine & $0.004 \mathrm{mg} \mathrm{L}^{-1}$ & {$[66]$} \\
\hline $\begin{array}{l}\text { cisplatin } \\
\text { carboplatin } \\
\text { oxaliplatin }\end{array}$ & CLC/ICP-MS & Rapid two-dimensional separation & human serum & $<2.4 \mathrm{ng} \mathrm{mL}^{-1}$ & [67]. \\
\hline total Pt & ICP-MS & Microwave digestion of the samples & $\begin{array}{l}\text { rat urine, plasma and } \\
\text { tissues }\end{array}$ & $5 \mathrm{ppb}$ & {$[68]$} \\
\hline $\begin{array}{l}\text { cisplatin } \\
\text { carboplatin }\end{array}$ & ICP-AES & Laboratory-prepared samples & urine & $0.1 \mathrm{mg} \mathrm{L}^{-1}$ & {$[69]$} \\
\hline oxaliplatin & ICP-MS & $\begin{array}{l}\text { Possible short-term storage of the } \\
\text { samples, for } 14 \text { days at }-4^{\circ} \mathrm{C},-24^{\circ} \mathrm{C} \text {, } \\
\text { and }-80^{\circ} \mathrm{C} \text {. Storage at }-80^{\circ} \mathrm{C} \text { allows } \\
\text { stability up to } 5 \text { months }\end{array}$ & $\begin{array}{l}\text { ultrafiltrate plasm } \\
\text { aurine } \\
\text { peritoneal fluid }\end{array}$ & $\begin{array}{l}1.76 \mathrm{ng} \mathrm{mL}^{-1} \\
0.39 \mathrm{ng} \mathrm{mL}^{-1} \\
0.20 \mathrm{ng} \mathrm{mL}^{-1}\end{array}$ & {$[70]$} \\
\hline cisplatin & $\mathrm{CV}$ & $\begin{array}{l}\text { nano-porous glassy carbon electrode } \\
\text { (npGCE) modified with graphene } \\
\text { quantum dots (GQDs) functionalized } \\
\text { with thionine groups }\end{array}$ & $\begin{array}{l}\text { blood serum and } \\
\text { urine samples }\end{array}$ & $90 \mathrm{nM}$ & [76] \\
\hline cisplatin & $\begin{array}{l}\text { adsorptive transfer } \\
\text { stripping and pulse } \\
\text { voltammetry }\end{array}$ & $\begin{array}{l}\text { drop electrode with metallothionine } \\
\text { protein }\end{array}$ & human serum & $0.5 \mu \mathrm{M}$ & [73] \\
\hline cisplatin & LC-MS/MS & - & rat plasma and urine & $1 \mathrm{ng} \mathrm{mL}^{-1}$ & [65] \\
\hline cisplatin & $\begin{array}{l}\text { differential pulse } \\
\text { voltammetry }\end{array}$ & $\begin{array}{l}\text { functionalization of screen printed } \\
\text { electrodes with carbon nanotubes }\end{array}$ & human serum & $4.6 \mu \mathrm{mol} \mathrm{L}-1$ & [77] \\
\hline cisplatin & ICP-MS & $\begin{array}{l}\text { determination of total platinum in } \\
\text { urine samples taken at }-20^{\circ} \mathrm{C} \text { after } \\
\text { collection }\end{array}$ & urine & $0.005 \mu \mathrm{g} \mathrm{L}^{-1}$ & {$[71]$} \\
\hline \multicolumn{6}{|c|}{ Environmental Samples } \\
\hline Compound & Method & Experimental Remarks & Sample & LOD & Ref. \\
\hline $\begin{array}{l}\text { cisplatin } \\
\text { carboplatin } \\
\text { oxaliplatin }\end{array}$ & ICP-MS & $\begin{array}{l}\text { Evaluated the total platinum and the } \\
\text { fraction in solution and adsorbed on } \\
\text { activated sludge }\end{array}$ & HWW & $10 \mathrm{ng} \mathrm{L}^{-1}$ & [48] \\
\hline total Pt & ICP-MS & $\begin{array}{l}\text { Sampling for several days from two } \\
\text { different hospital drains one after the } \\
\text { oncological ward }\end{array}$ & HWW & $15 \mathrm{ng} \mathrm{L}^{-1}$ & {$[54]$} \\
\hline total Pt & ICP-MS & $\begin{array}{l}\text { Determination of total platinum from } \\
\text { WWTP and HWW effluents }\end{array}$ & $\begin{array}{l}\text { WWTP } \\
\text { HWW }\end{array}$ & $1.0 \mathrm{ng} \mathrm{L}^{-1}$ & {$[55]$} \\
\hline
\end{tabular}


Table 2. Cont

\begin{tabular}{|c|c|c|c|c|c|}
\hline \multicolumn{6}{|l|}{ Biological Samples } \\
\hline Compound & Method & Experimental Remarks & Sample & LOD & Ref. \\
\hline total Pt & HPLC-ICP-MS & $\begin{array}{l}\text { Determination for the influent and } \\
\text { effluent of a pilot MBR for several } \\
\text { months }\end{array}$ & HWW & $10.0 \mathrm{ng} \mathrm{L}^{-1}$ & {$[79]$} \\
\hline total Pt & ICP-MS & $\begin{array}{l}\text { Samples taken from the influent and } \\
\text { effluent of a WWTP and from the } \\
\text { effluent of a hospital, both located in } \\
\text { Gran Canaria island. Samples stored } \\
\text { at }-4^{\circ} \mathrm{C} \text { and then extracted. }\end{array}$ & $\begin{array}{l}\text { WWTP } \\
\text { HWW }\end{array}$ & $0.74 \mathrm{ng} \mathrm{L}^{-1 \mathrm{a}}$ & [81] \\
\hline $\begin{array}{l}\text { cisplatin, carboplatin, } \\
\text { oxaliplatin, } \mathrm{PtCl}_{4}{ }^{2-} \mathrm{PtCl}_{2}\end{array}$ & FIA-ED & $\begin{array}{l}\text { electrochemical detector consisting in } \\
\text { a glassy carbon electrode as a working } \\
\text { electrode }\end{array}$ & Ponavka river & - & [83] \\
\hline total Pt & ICP-OES & $\begin{array}{l}\text { Samples taken from several hospitals } \\
\text { of the city of Qom }\end{array}$ & HWW & $1 \mu \mathrm{g} \mathrm{L}^{-1}$ & {$[84]$} \\
\hline $\begin{array}{l}\text { cisplatin } \\
\text { carboplatin } \\
\text { oxaliplatin }\end{array}$ & HPLC-ICP-MS & $\begin{array}{l}\text { pentafluorophenylpropyl- } \\
\text { functionalized silica gel } \\
\text { column }\end{array}$ & HWW & $\begin{array}{l}0.09 \mu \mathrm{g} \mathrm{L}^{-1} \\
0.10 \mu \mathrm{g} \mathrm{L}^{-1} \\
0.15 \mu \mathrm{g} \mathrm{L}^{-1}\end{array}$ & [86] \\
\hline
\end{tabular}

a instrument LOQ.

In 2015, the PEC/analytical study at the hospitals of Qom [57] correlated the calculate calculated $\mathrm{RQ}_{\mathrm{hww}}$ was 1.19. ICP-OES, and limit of detection was determined (LODs $\left.=1 \mu \mathrm{g} \mathrm{L}^{-1}\right)$.

In addition to the methods for determining the concentration of the platinum-based drugs, the separation methods for these compounds are also important. For example, pentafluorophenylpropyl-functionalized silica gel was employed to separate platinumbased drugs, and HPLC-ICP-MS was used to the determinations of cisplatin and its hydrolysis products, carboplatin, and oxaliplatin in urine sample and in HWW samples [86]. The limits of detection determined were $0.09,0.10$, and $0.15 \mu \mathrm{g} \mathrm{L}^{-1}$ for cisplatin, carboplatin, and oxaliplatin, respectively. Moreover, the stability of carboplatin and oxaliplatin, at different chloride concentrations to simulate the conditions of WW and surface water, was obtained using this method. The results indicated that carboplatin was stable in pure water and in $1.5 \mathrm{~mol} \mathrm{~L}^{-1} \mathrm{Cl}^{-}$solutions, while oxaliplatin degradation was improved by increasing the concentration of the chloride.

The determinations of cisplatin, its hydroxo complexes, and $\mathrm{OH}$-dimers were obtained using HPLC with a naphthylethyl (NAP) group bonded with silica gel column. The mobile phase was constituted by $0.1 \mathrm{M}$ sodium perchlorate, acetonitrile, and perchloric acid (290:10:3) [87]. The measurable range was $1 \times 10^{-5}$ to $4 \times 10^{-3} \mathrm{M}$ for cisplatin the calibration curves correlation coefficient was $0.999(p<0.01)$ and the time of retentions time was 3.2, 3.4, 3.6, and 4.3-6.6 min for cisplatin, mono-chloride, $\mathrm{OH}$-dimer, and none-chloride respectively. Moreover, the authors state that the determinations of cisplatin could be done by means of a $\mu \mathrm{NAP}$ column instead of an aminopropyl silyl silica gel column or C-18 column.

The results showed that separation was completed in approximately 2 min with column temperature at $30^{\circ} \mathrm{C}$. In cationic separation, the cisplatin elutes first, the opposite behavior was exhibited by the anionic one, and in both cases a second peak was detected and was attributed to a hydrolysis product of the drug. However, better results were obtained with the use of cationic chromatographic column where the detection limits were $0.1 \mathrm{mg} \mathrm{L}^{-1}$ of $\mathrm{Pt}$ for both compounds, whereas the repeatability oscillated from $3.1 \%$ to $5.9 \%$.

The authors also observed that this method does not require special treatment and has been characterized by low cost and low time analysis, therefore making it a suitable method for the analysis of urine from cancer patients after clinical treatment with cisplatin and carboplatin. 


\subsubsection{Working Environments}

The Pt-CDs (and other CDs) contamination in working environments has been carried out in several studies where biological and/or environmental (surfaces, air) samples were considered.

In 1997 Nygren and Lundgren [88] reported the results of a study in which the platinum in blood and urine and air samples was determined by adsorptive voltammetry. No different levels of airborne Pt were found in oncological wards with respect to empty rooms. Authors reported that staff nurses had the highest Pt levels, possibly due to the closer contacts with the patients, and that improved facilities and procedures could decrease contamination.

Occupational exposure of pharmacy technicians and pharmacists of 14 different hospitals in Germany to several CDs (including Pt-CDs) was also monitored and the samples were analyzed by GC-MS (gas chromatography MS), HPLC, and voltammetry (for Pt LOD: $1 \mathrm{ng} \mathrm{L}^{-1}$ urine) [89]. They found that in some cases Pt was detected in the urine of the screened personnel. This suggested that improved $C D$ manipulation and storage protocols should have been implemented. Additionally, in this work it was concluded that the probability of airborne contamination was very small (as also in ref. [88]).

An interesting study concerned the determination of residual cisplatin present in rinse water used to clean surfaces exposed during manufacturing [90]. In this study the samples were obtained by swabbing the surfaces with a derivatizing solution and then analyzing with HPLC with UV detection. Additionally, in this case, detection was made using DDTC to complex Pt(II) to enhance the sensitivity of UV-Vis measurements.

Hori et al. [91] studied the Pt present in hair and surface wipe samples obtained from hospital workers who had or had not manipulated Pt-CDs, patients treated with $\mathrm{Pt}$-CDs, and non-medical staff. Samples were collected then, and at 5-year distance. Pt content was determined by ICP sector field mass spectrometry (ICP-SFMS) with a LOQ of $0.001411 \mathrm{ng} \mathrm{mL}^{-1}$ and $0.001271 \mathrm{ng} \mathrm{mL}^{-1}$ in the two sets of samples. This interesting study suggested that trace level $\mathrm{Pt}$ from exposure to $\mathrm{Pt}-\mathrm{CD}$ s was associated with the frequency of handling of such compounds and a significant decrease of contamination after the revision of a safety procedures was observed.

A rapid LC-MS/MS method was developed to analyze a group of six CDs including oxaliplatin on stainless steel [92]. The samples were analyzed by HPLC-MS/MS with a LOD of $1.36 \mathrm{ng} \mathrm{mL}^{-1}$. This method could be applied to accurately determine surface contamination at concentrations below the recommended levels [92] and therefore it is suitable for monitoring purposes.

A study on the exposition to CDs at patients' homes has been carried out by Böhlandt et al. [93]. Even if it does not concern working environment, the sampling techniques are similar. Additionally, it is important as other works $[54,56,79]$ concluded that the release of Pt-CDs in the environment does not occurs primarily from the hospitals. In ref. [93], wipe samples from several homes and urine samples were collected from patients and family members. Samples were analyzed for several CDs including platinum (as marker of Pt-CDs). Significant contamination was found on every surface type with highest concentrations in bathroom surfaces. While patients' urinary drug concentrations often were elevated for more than $48 \mathrm{~h}$ after administration, no drug residues were detectable in the family members' urine.

\section{Predicted Behavior in the Aquatic and Related Environments}

The specific physicochemical properties of the platinum-based CDs play central roles in defining the environmental behavior and fate of the compounds. Subsequent to excretion from the human body, both unaltered compounds and their metabolites go through a series of biological, chemical, and physical transformations in the environment. Hydrolysis, photolysis, dilution, adsorption to suspended solids sedimentation, and biodegradation are some of the processes to which cytostatics are exposed. This phenomenon usually results in degradation products with new chemical properties [6]. 
The transport of cisplatin, carboplatin, and their respected derivatives in watersaturated sand and natural soil columns was investigated [94]. Aliquots of a concentrated carboplatin stock solution and a background electrolyte solution were added to prepare the carboplatin solutions; this procedure would favor the equilibrium of its different monomer species by dissociating the carboplatin dimers. However, the authors state that this process should be incomplete within the time frame of this experimentation, which could consequently affect subsequent results [94]. On the other hand, cisplatin inlet solution was predicted to show continuous alteration in the current experiment. In aqueous solution the chloro-ligands are substituted by water gradually forming monoaquo species $\left(\mathrm{PtCl}\left(\mathrm{OH}_{2}\right)\left(\mathrm{NH}_{3}\right)_{2}\right)^{+}(\mathrm{pKa} \approx 6.3-6.8)$ and di-aquo species $\left(\mathrm{Pt}\left(\mathrm{OH}_{2}\right)_{2}\left(\mathrm{NH}_{3}\right)_{2}\right)^{2+}$ $\left(\mathrm{pKa}_{1} \approx 5.5, \mathrm{pKa}_{2} \approx 7.3\right)$, which further convert to $\left(\mathrm{Pt}\left(\mathrm{NH}_{3}\right)_{2} \mathrm{OH}\left(\mathrm{OH}_{2}\right)\right)^{+}(\mathrm{pKa} \approx 5.5)$ and $\left(\mathrm{Pt}\left(\mathrm{NH}_{3}\right)_{2}(\mathrm{OH})_{2}\right)(\mathrm{pKa} \approx 7.2)$ at increased $\mathrm{pH}$. Similar values were obtained in pure water [30]. Moreover the experimental rate constants $(k)$ of the hydrolysis reactions were obtained, being $7.59 \times 10^{-5} \mathrm{~s}^{-1}$ for the formation of mono-aquo species [34] and $2.5 \times 10^{-5} \mathrm{~s}^{-1}$ for the formation of di-aquo species [35].

In conclusion, a stable plateau at recovery levels of $96-100 \%$ was reached from carboplatin species very slow retention by the medium surfaces. The plateaus were stable and unaltered by changes in redox, showing that carboplatin remains both unchanged, probably due to an incomplete transformation, and unreactive. In case of cisplatin, the main differences between sand and soil were the higher retardation factors $\left(R_{f}\right)$ in soil (2.0 vs. 1.0$)$ and the somewhat higher recovery in sand $(70 \%$ at the peak of the breakthrough curves vs. $50 \%$ ). Cisplatin species showed strongest chemisorption to soil surfaces, compared to those of carboplatin and oxaliplatin. This behavior was related to the formation of $\mathrm{H}$-bonding or electrostatic interactions between aquo or hydro groups and soil $\mathrm{O}-$, and aquo or hydro are better leaving ligands able to bound the soil terminal groups [94].

The stability of carboplatin in aqueous solution has been measured as function of temperature, chloride concentration, $\mathrm{pH}$, ionic strength, medium material, and illumination $[95,96]$. Di Pasqua et al. in 2012 [97] reported that the rate of the ring opening reaction was related, to a greater extent, on the nucleophile concentrations and $\mathrm{pH}$ (e.g., chloride, carbonates, phosphates) of the medium, and that in all cases this process is slower than cisplatin activation. Carboplatin has also been shown to exist in a non-reactive dimer in concentrated aqueous solutions [97].

The transport of oxaliplatin and its derivatives in saturated sand and soil columns was investigated by mimicking environmentally relevant, non-equilibrium (or quasiequilibrium) conditions and reflected the mutual interaction between dispersion, diffusion, i.e., advection, transport mechanisms, along with relations with the soil, for example, precipitation, sorption or biodegradation of the pharmaceuticals [98]. The authors found that, depending on the composition of the solution and the electrolyte activity, oxaliplatin is inclined to transformation into aqueous solutions. At the beginning of the experiment, the most probable oxaliplatin species according to the $\mathrm{pH}$, temperature, composition, and solution were oxaliplatin, $(\mathrm{Pt}(1,2 \text {-diaminocyclohexane })(\mathrm{ox}) \mathrm{Cl})^{-},(\mathrm{Pt}(1,2-$ diaminocyclohexane $\left.) \mathrm{Cl}_{2}\right)$, and $\left(\mathrm{Pt}(1,2 \text {-diaminocyclohexane }) \mathrm{Cl}(\mathrm{OH})_{2}\right)^{+}$. The type of porous medium, that constitutes the columns of soil and sand, has a significant impact on the transport characteristics of oxaliplatin, while cation activity in the inlet solution and the redox conditions has a lesser effect. However, none of soil redox conditions or the chelators were able to induce a sufficient, long-term retardation mechanism for oxaliplatin and oxaliplatin-related species. One of the implications of these results was that the efforts to reduce oxaliplatin transport in soil-water environments by manipulations of $\mathrm{pH}$ or redox conditions would not be enough to prevent groundwater contamination. The authors concluded that the best way to avoid contamination from these compounds is to collect and treat hospital effluents at the source, before they are released into the aquifer and the environment from groundwater [98].

From these studies, the authors conclude that despite the structural similarities between oxaliplatin, carboplatin, and cisplatin, their transport characteristics are quite differ- 
ent. Therefore, when establishing and or predicting pharmaceutical fates in the environment, the development remediation solutions should be done separately and according to the particular characteristics of every one of them [94].

\section{Ecotoxicological Potency}

The environmental distribution of platinum-based anticancer drugs and their metabolites are particularly poorly defined [99]. A recent review analyzing data from numerous studies on CDs toxic effects evidenced that toxicity was also dependent on the compound and the organism, and that multi-generational exposure was more important to recognize the impact of CDs, which at environmental concentrations do not seem to be harmful [100].

In ref. [101] the analysis of the exposure of the green alga P. subcapitata and the cyanobacterium S. leopoliensisthe to cisplatin concluded that the "no effect levels" were higher than predicted environmental concentrations, and that synergistic negative effects, due to the simultaneous presence of different CDs, could pose an additional risk.

In 2008, Supalkova et. al. reported an investigation of affecting of duckweed (L. minor) by different concentrations $(0-160 \mu \mathrm{M})$ of cisplatin for 4 days [102]. Growth inhibition expressed as decrease in number of leaves and slowed growth rate. Total amount of biomass was used as parameters to quantify the toxicity of cisplatin. After $96 \mathrm{~h}$, the half maximal effective concentration $\left(\mathrm{EC}_{50}\right)$ was $6.93 \mu \mathrm{M}$ and was calculated from growth inhibition with comparison of growth rates. In the same work, the authors, using differential pulse voltammetry, were able to determine the concentrations of cisplatin, and the highest value, $320 \mathrm{ng} \mathrm{g}^{-1}$, was obtained on the second day of treatment with $80 \mu \mathrm{M}$ of cisplatin. Moreover, a marked increase in cysteine-rich peptides was observed, which are synthetized by plants to protect themselves against heavy metals.

Bioaccumulation of oxaliplatin in L. minor was recently determined by exposing the aquatic plant to three concentrations of the drug $\left(0.4-100 \mu \mathrm{g} \mathrm{mL}{ }^{-1}\right)$ for seven days [103]. The majority of oxaliplatin was internalized by L. minor, but only at the medium/high concentrations plant growth was negatively affected. Authors concluded that oxaliplatin is unlikely to be phytotoxic at concentrations typically encountered in the environment and that $L$. minor is not a suitable biomonitor or phytoremediator of contaminated waters.

Parrella et al. [104] investigated the acute and chronic toxicity of 6 CDs including cisplatin on several aquatic (D. magna, C. Dubia, B. Calyciflorus, and T. Platyurus). Acute effects were observed at concentrations higher (in the $\mathrm{mg} \mathrm{L}^{-1}$ range) than those predicted in the environment, while chronic toxicity tests were conducted with the compound in the $\mu \mathrm{g} \mathrm{L}{ }^{-1}$ range Cisplatin resulted among the most toxic compounds in both conditions.

By means of "scanning ion-selective electrode technique" (SIET) the in vivo functional alteration of zebrafish hair cells/ionocytes induced by cisplatin was investigated [105]. This method resulted much more sensitive than survival studies in detecting alterations in aquatic animals due to exposure of cisplatin.

Cisplatin was added to cultures of the marine macro alga, Ulva lactuca, in different types of water for a period of time of $48 \mathrm{~h}$ [106]. The results showed that the accumulation of cisplatin in the alga was greater when cisplatin was added from distilled water with respect to seawater (as expected on the basis of the greater amount of the aqua-complex) and that was not phytotoxic at the concentrations employed $(<150 \mathrm{nM})$.

The environmental risk of cisplatin and other CDs was determined by a variety of indicator organisms [107]. The obtained RQ value higher than 100 for cisplatin and imatinib mesylate (a non Pt-CD) indicated the potential adverse effects but also no environmental risks.

Although environmental concentrations of cancer drugs are unlikely to cause fatal effects on edible plants, these chemicals can accumulate in their organisms causing longterm damage and affecting their normal growth and development [108].

The effects of the exposition of four edible plants, Raphanus sativus, Lactuca sativa, Brassica rapa, and Triticum durum to the antineoplastic drugs 5-FU and cisplatin at two different concentrations, 10 and $100 \mu \mathrm{g} \mathrm{L}^{-1}$, were investigated [108]. Here, the authors 
investigated the metabolome of the plants prior and post treatment with the drugs by NMR spectroscopy with the purpose of detecting biochemical alterations in the plants. The comet test, which uses human lymphocytes, is a sensitive system for assessing damage in immune cells and has been used to assess the potential for genotoxic damage related to human exposure to treated plants [108]. When plants were exposed at $100 \mu \mathrm{g} \mathrm{L}^{-1}$ of cisplatin, the \% DNA in tail increased from $29 \%$ to $62 \%$, in B. rapa, L. sativa, R. sativus, and T. durum, respectively; similar results were obtained for 5 -FU $(40 \%, 32 \%$, and $47 \%$ in $L$. sativa, R. sativus, and T. durum respectively). Significant DNA damage was observed when lymphocytes were treated with cisplatin or 5-FU. An interesting result from this study was the significant increase of the DNA strand breaks in lymphocytes exposed to the extracts of the plants exposed to the cytostatics, compared with the DNA damage observed in lymphocytes exposed to the individual drugs. Although this is a preliminary study, the results leads to a better understanding of the potential risks on human health in relation to the use of recycled waters for the irrigation of edible plant [108].

A freshwater microalgae Chlorella vulgaris was used to test the toxicity of cisplatin, oxaliplatin, and carboplatin in different concentrations $\left(100-600 \mathrm{mg} \mathrm{L}^{-1}\right)$ and exposition time [109]. Throughout the experiments, malondialdehyde (MDA) release, antioxidant potential, synthesis of photosynthetic pigments, and protein content were determined. The half maximal inhibitory concentration $\left(\mathrm{IC}_{50}\right)$ of cisplatin, carboplatin, and oxaliplatin ranged from 106.2 to $153.9 \mathrm{mg} \mathrm{L}^{-1}$ after $96 \mathrm{~h}$ of exposure. Moreover, a decrease in synthesis of chlorophyll a, chlorophyll $b$, cell proliferation, and algal protein content were observed in a time and dose-dependent manner. Furthermore, the antioxidant potential decreased, while the release of MDA in the culture media increased. Cisplatin had more toxic effects on C. vulgaris in respect to carboplatin and oxaliplatin, indicating its severe toxicity for marine organisms.

The release of cisplatin in aquatic environments can also have effects on aquatic fauna; in particular, the effects on the physiological parameters and swimming behavior of Daphnia magna was studied at different concentrations of cisplatin $\left(125-1000 \mu \mathrm{g} \mathrm{L}^{-1}\right)$ by using video digital analysis [110]. The authors demonstrated that the travel behavior, such as swimming speed, distance travelled, propelling efficiency, and hopping frequency were inhibited in a time and concentration-dependent manner. Moreover, also physiological parameters, such as thoracic limb activity and heart rate, were affected by exposure. This study suggests that since cisplatin affected daphnid parameters at the environmental concentration, it should be considered as hazardous to zooplankton.

The toxicity of cisplatin, at environmental concentrations (i.e., $0.1,10$, and $100 \mathrm{ng} \mathrm{Pt} \mathrm{L}{ }^{-1}$ ), on polychaete Nereis diversicolor, also known as ragworm, was investigated [111]. Different parameters (neurotoxicity, genotoxicity, behavioral impairment, ion pump effects, oxidative stress, metal exposure, biotransformation, and oxidative damage) was used to evaluate the sublethal responses after 14-days of exposure in a water-sediment system. Neurotoxic effects and significant burrowing impairment were observed when ragworm was exposed to $100 \mathrm{ng} \mathrm{L}^{-1}$ of Pt solution. The inhibition of antioxidant enzymes, such as superoxide dismutase and catalase, and second phase biotransformation enzyme, glycosyltransferases, were compensated by metallothionein-like protein induction and an increase in lipid peroxidation levels. Authors concluded that the release of cisplatin into the waterbodies may pose a risk to this aquatic species even at the range of $\mathrm{n} \mathrm{L} \mathrm{L}^{-1}$.

The impact of cisplatin (and other CDs) on the DNA damage level was studied in vivo and in vitro on hemocytes of freshwater mussels Unio sp. (U. pictorum/U. tumidus) [112]. An impact on the level of DNA damage has been detected, however the highest concentration of cisplatin $(4 \mu \mathrm{M})$ was one order of magnitude higher than that detected in HWW.

Changes in oxidative stress in target organs, antioxidant capacity, and DNA damage in hemocytes of Mytilus galloprovincialis were observed along with neurotoxicity when exposed to $100 \mathrm{ng} \mathrm{L}^{-1}$ of cisplatin [113]. 
Additionally, the exposure of Mellita quinquiesperforata larvae to solutions containing cisplatin at $\mathrm{ng} \mathrm{L}^{-1}$ levels (also data for $\mathrm{CP}$ and tamoxifen) displayed effects on the development of the embryos [114].

Another study evaluating the exposure of Daphnia pulex and Daphnia pulicaria to cisplatin (also CP) evidenced several effects such as the decrease of eggs number, modified expression of some proteins, and increased level of enzymes participating in DNA repair [115].

The effect of functionalized polystyrene nanoplastics (carboxylate and aminefunctionalized, as models for cationic and anionic nanoplastics, respectively) on cisplatin, oxaliplatin and carboplatin transport, and toxicity was studied by Nath et al. [116]. In the soil-water environment, carboplatin was found to be highly mobile, while cisplatin and its derivatives (Figure 3) are intermediately mobile and oxaliplatin presents low mobility. Nanoplastics increased the mobility of the Pt-CD of cisplatin and oxaliplatin, while amine-functionalized ones slightly decreased the mobility of carboplatin in soil. As far as toxicity is concerned, authors showed that nanoplastics themselves are not toxic for the soil microbes, but their presence can increase the toxicity of Pt-based CDs (as of any other pollutant) by altering their mobility [116].

\section{Impact of Water Treatment Technologies}

The ability of different water treatment technologies in the removal of CDs from water has been assessed in several studies [117]. Treatments with biological components, physico-chemical separation, and advanced oxidation processes (AOPs) are some of the most studied methods [6]. In general, these methods include MBR [118], MBR with a UV irradiation technology post-treatment [119], adsorbents based on granular or powder activated carbon [120], or, recently, metal-organic frameworks (MOFs) [121], membrane filtration [120], electrolysis [122], ozonation [123], photocatalytic membrane reactors [124], and more recently applied, adsorbents based on cryogels [125].

The overall removal efficiency can vary between different cytostatic compounds and depends on their physicochemical properties and biodegradability [6]. Not all processes are equally efficient for all compounds present in a WW sample, so the best strategy to achieve the best performance could be the combination of several of the existing methods.

The removal of platinum based cytostatics form WW has not been extensively studied and just a few methods have been proved to be useful for it. The treatment in MBR-systems, the application of AOPs, and more recently the successful studies with cryogels based adsorbents are, so far, the studied methods for platinum drugs removal.

\subsection{Membrane Bioreactors}

MBR technologies are, as the name suggests, those technologies that provide biological treatment with membrane separation [126]. MBR is a wastewater treatment technology over the activated sludge process (ASP); ASP technology has been the conventional municipal WWs treatment over the last century [127]. MBR is, in fact, one of the most significant innovations in WWTP $[127,128]$, since the technology reduces the drawbacks of the conventional ASP, including production of excess sludge, liquid-solid separation issues, large space requirement for secondary clarifiers, and limitations with removal of recalcitrant (Figure 5) [129]. Although MBR is a hybrid between biological treatment and filtration, in some cases chemicals are introduced to improve performance. MBRs can be applied for the removal of organic and inorganic contaminants, and they are able to produce high-quality effluents, which can be reused in other processes [129].

Theoretically, the biotransformation and mineralization of pharmaceutically active compounds (PhACs) can be regulated by adjusting the operating conditions in MBRs [130]. The degradation of pollutants with low bio-degradability and low concentration may be achieved with MBR technology [118]. This is possible because the MBR generally operates at high biomass concentrations and high sludge retention times, allowing an intensification of the biological process by implementing resistant and low-growing biomass [131]. 


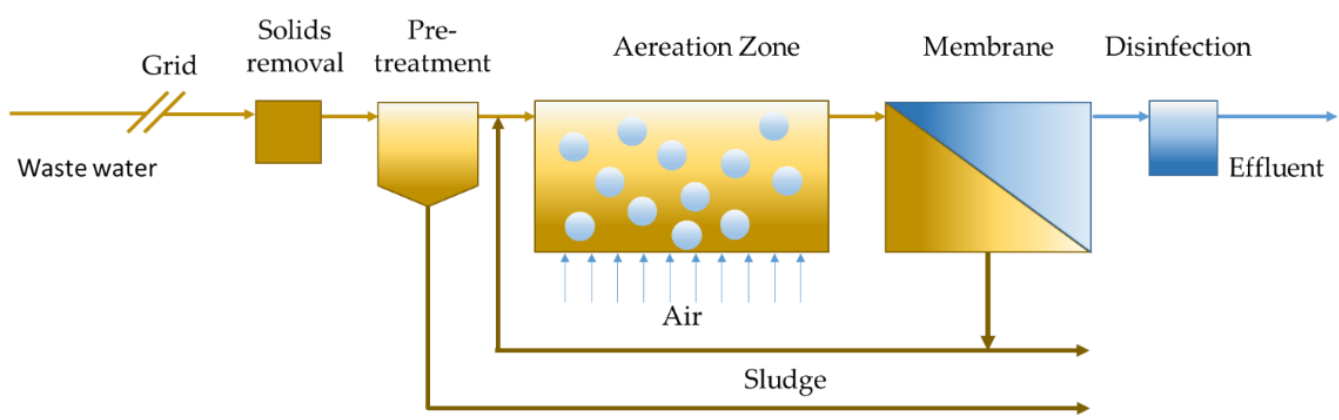

Figure 5. Schematic representation of membrane bioreactor (MBR) process.

In 2007 [53], the efficiency of MBR in platinum CDs removal from HWW was assessed. In this work, Pt CDs was studied using two different methods, batch laboratory experiments with ASP, and a pilot MBR system installed in a hospital [53]. In the experiments performed in the MBR, the ICP-MS analysis was used to monitor the concentrations of Pt in influent (3-250 $\left.\mu \mathrm{g} \mathrm{L}^{-1} \mathrm{Pt}\right)$ and the effluent $\left(2-150 \mu \mathrm{g} \mathrm{L}^{-1} \mathrm{Pt}\right)$. The elimination efficiencies ranged between $51 \%$ and $63 \%$. Speciation by HPLC-ICP-MS indicated that mainly carboplatin was present as intact drug in the influent, and in the effluent of the MBR as poorly adsorbed by the particulate (see also Section 5.3). Advanced WW treatment using a MBR was shown to provide an appropriate method for lowering platinum compounds concentrations before discharge into the environment [53].

The fate of cisplatin, carboplatin, oxaliplatin, and other organic CDs in HWW in Vienna were also investigated [79]. Interestingly, in this study, a correlation between the administrated dosage and measured concentrations was drawn. A pilot MBR, coupled with advanced WW treatment processes (UV irradiation and activated carbon adsorption) was used for the treatment of WW from oncological wards. The result obtained indicated that in the MBR-system platinum compounds were removed by $60 \%$, much lower than organic CDs. This was related mainly to the different mechanisms of biodegradation and adsorption of the compounds. In the case of platinum compounds, similar concentrations of total $\mathrm{Pt}$ were detected during the four monitoring periods, probably due to a too short contact time between the WW and the activated sludge [79]. Finally, it was shown that only $27-34 \%$ of total administrated Pt was found in the HWW, which can be explained by a short in-patient stay in comparison to the biological half-life of platinum compounds.

Adsorption to activated sludge was the mechanism of $\mathrm{Pt} C D$ s elimination in the MBR $[53,79]$. On the other hand, the genotoxic effects could be significantly reduced by the MBR-system, which allowed the classification of WW as "low-risk" in a preliminary risk assessment.

\subsection{Advanced Oxidation Processes}

AOPs are used today for the treatment of a wide range of contaminants [132-134]. These processes are based on the in situ generation of highly reactive species such as reactive oxygen species (ROS), in particular hydroxyl radicals ( $\mathrm{HO} \cdot), \mathrm{H}_{2} \mathrm{O}_{2}, \mathrm{O}_{3}$, and superoxide anion radicals $\left(\mathrm{O}_{2}{ }^{-}\right)$.

AOPs have low selectivity; however, some species, such as sulfate radicals or singlet oxygen, have a selective oxidation and are able to provide a complete mineralization of contaminants to $\mathrm{CO}_{2}, \mathrm{H}_{2} \mathrm{O}$, and inorganic ions or acids.

AOPs are characterized by different modes of action such as ozonation [107], Fenton [135], photo-Fenton [135], photocatalysis [136], radiation [137], sonolysis [138], and elec-trochemical oxidation (electrolysis) [122,139]. AOPs has been used for the treatment of cisplatin particularly. For instance, the ozonation in buffered and non-buffered solutions at $\mathrm{pH} 9$ and at $303 \mathrm{~K}$ using a semi-batch reactor was investigated [123]. Ozone is a highly reactive species and a strong oxidant that is used in degradation of contaminants in industrial WWTP [132]. Isocratic reverse phase high-performance liquid chromatography (RP-HPLC) and electrospray tandem mass spectrometry (ESI-MS/MS) was used for the determination 
of cisplatin and its reaction products. The main results indicated that cisplatin ozonation reactions, at non-buffered and buffered solutions, showed a pseudo-first-order rate constant (k) of $3.86 \times 10^{-2} \mathrm{~s}^{-1}$ and $3.76 \times 10^{-2} \mathrm{~s}^{-1}$, respectively, for cisplatin consumption. Cisplatin degradation occurred before the solution turned acidic, indicating that this degradation follows a radical pathway if the $\mathrm{pH}$ of the solution allows a significant decomposition of ozone into hydroxyl radicals.

Moreover, the pseudo-second-order rate constant for the reaction of cisplatin with $\mathrm{HO} \cdot$ at $303 \mathrm{~K}$ was determined by competition kinetics with the use of reference compound (p-chlorobenzoic acid). The rate constant found was $6.42 \times 10^{10} \mathrm{M}^{-1} \mathrm{~s}^{-1}$, a value similar to many other compounds found in literature [140]. In the non-buffered solution cisplatin disappeared after two mins of reaction with $99 \%$ conversion and the $\mathrm{pH}$ decreased from 9.0 to 3.5. The analysis of the non-buffered solution by ESI-MS/MS showed that the main product of the ozonation reaction was diamminedichlorodihydroxo platinum (IV) and, in this condition, it remains unaltered. Similar results are found in buffer solution. Finally, the ozonized solutions after $240 \mathrm{~min}$ were found to be non-mutagenic.

The products obtained during an electrolysis could contain hypochlorite, so this technique has been mainly studied in terms of application to disinfection and sterilization. The electrolysis of sodium chloride solution generates hypochlorite, and it has been reported that this process can lead to the inactivation of antineoplastics present in solution [122].

The biological cytotoxicity of the electrolyzed compounds of irinotecan hydrochloride, vincristine sulfate, mitomycin $C$, paclitaxel, methotrexate, and cisplatin was studied by electrolytic treatment using a constant current of $100 \mathrm{~mA}$ through two platinum electrodes [122]. The results indicated that $72.100-99.999 \%$ of the toxicity was eliminated by the process of electrolysis.

A few years later Kobayashi et al. in 2008 [139] designed an apparatus (Figure 6) useful for the inactivation and detoxification of WW containing antineoplastics from a hospital. The apparatus was designed to provide free chloride in the $\mathrm{pH}$ range 9.0-10.0.

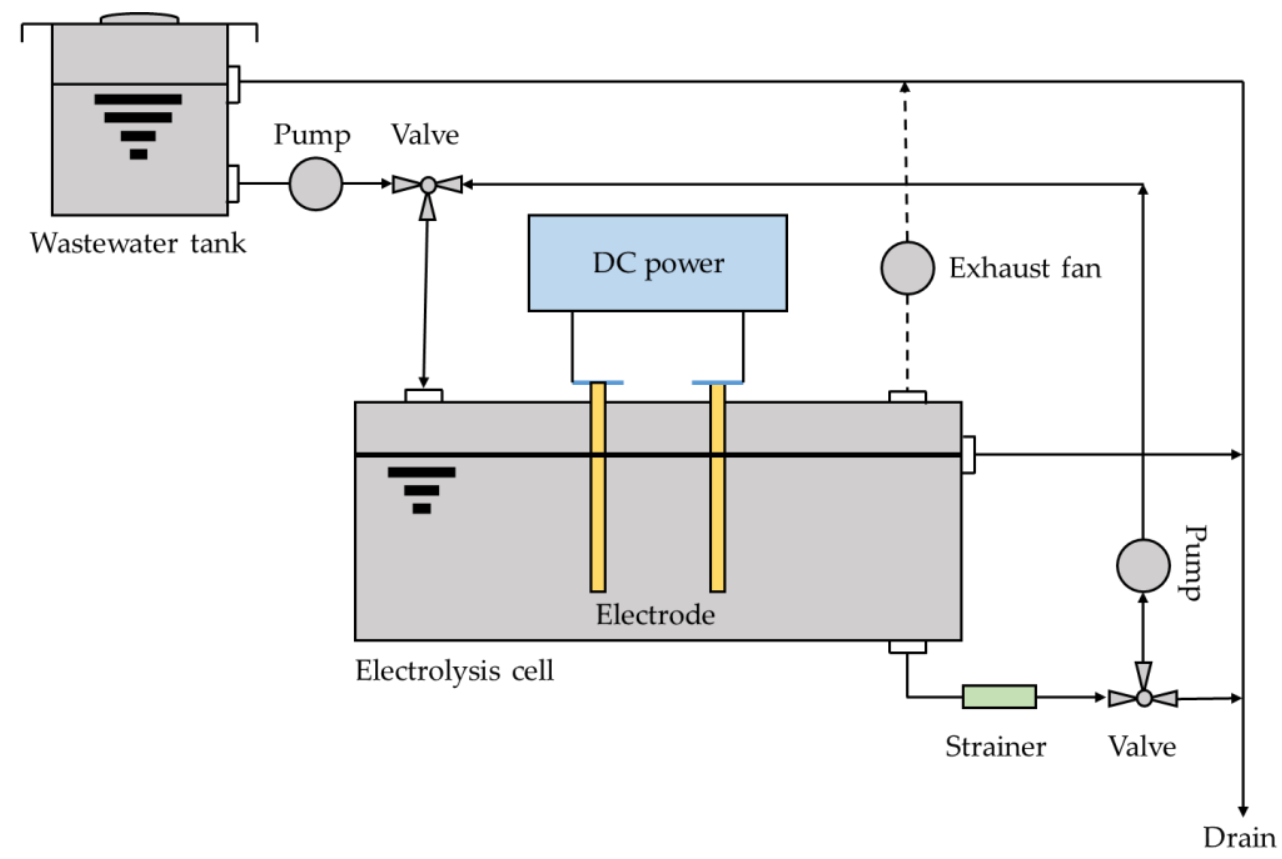

Figure 6. Schematic representation of electrolysis apparatus.

The chloride ion becomes free chlorine at the anode upon oxidation. Then free chlorine reacts with water, and hypochlorite ion is generated in alkaline solution. The generated hypochlorite ion oxidizes antineoplastics and is reduced to the chloride ion. It is speculated that chlorine reactivation in the circulating system is the main mechanism for inactivation of toxicity in antineoplastics. As a result of this study, the efficacy of 
the apparatus was evaluated with 26 clinical WW samples, including alkylating agents, antimetabolites, antitumor antibiotics, platinum pharmaceuticals, etc. and in almost all samples inactivation rate was above $90 \%$ [139].

The advantage of this method is the lower cost respect to the dilution method, which makes electrolysis both effective and economically valuable [139].

\subsection{Adsorption}

The use of adsorbent materials can help an efficient removal of CDs from WW by concentrating the target drugs before their degradation. Among the different WW treatment methods adsorption technologies present a low-cost option which can be easily implemented and coupled with other methods and integrated in existing WWTPs [141,142].

Several studies focused on adsorption of Pt CDs mostly for designing drug delivery systems, for example mesoporous silica [143], silica nanoparticles [144], carbon nanotubes [145-147], magnetic nanoparticles [148], polymers and polymeric micelles [149], and biopolymers [150]. Despite the physicochemical phenomena at the basis of nanomaterial loading for drug delivery and removal from water, fewer studies have been developed for the latter purpose.

Folens et al. [71], by analyzing the urine excretion of several patients and drug consumption at Ghent hospital, found that the excretion rate is almost zero after $24 \mathrm{~h}$. Therefore, to recover platinum and avoid environmental pollution the urine excreted by the patients at the hospital could be directly treated. They suggested that direct adsorption on activated carbon or portable cartridges which could be used at home; however, they pose safety concerns, due to possible contamination. Alternatively, the urine could be collected in separate toilets provided with an adsorption material and treated in a centralized way with lower operational cost [71]. Some of the same authors later proposed biomass-derived adsorbents (chitosan, biochar, wood ash, activated carbon) for removing platinum from diluted samples, including synthetic human urine [151]. The adsorption was found to be between 0.23 and $0.97 \mathrm{mg} \mathrm{g}^{-1}$ of inorganic $\mathrm{Pt}(\mathrm{IV})$ with an adsorbent dose of $10 \mathrm{~g} \mathrm{~L}^{-1}$. They obtained significant differences in platinum adsorption depending on the species involved (inorganic platinum, cisplatin, carboplatin).

The adsorption of cisplatin was performed using calcinated gibbsite: equilibrium adsorption of cisplatin was obtained within $24 \mathrm{~h}$, with an optimal loading at $\mathrm{pH}$. The negative $\Delta \mathrm{G}$ and $\Delta \mathrm{H}$ values obtained indicated chemisorption [152]. Desorption experiments were conducted by treating the material with hydrochloric acid which reached a nearly complete recovery of Pt.

Cisplatin, carboplatin, and oxaliplatin adsorption by ASP was studied by Lenz

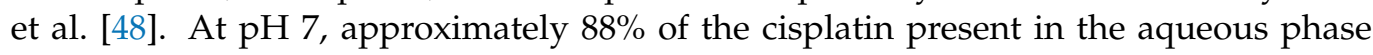
was adsorbed, while carboplatin and oxaliplatin were removed in smaller quantities (approximately $26 \%$ and $54 \%$ respectively). Adsorption in HWW and activated sludge of different sampling sites displayed strong variations in the first case, whereas activated sludge exhibited more similar elimination \%. The authors concluded that WWTPs are able to remove most $\mathrm{Pt} C D$ s presents, as they are adsorbed by the solid phase in the water cycle. [48]. In ref. [53], the adsorption coefficient $\left(K_{\mathrm{D}} \mathrm{L} \mathrm{kg}^{-1}\right)$ and the organic carbonnormalized coefficient $\left(\mathrm{K}_{\mathrm{OC}}\left(\mathrm{L} \mathrm{kg}^{-1}\right)\right)$ were determined for adsorption onto ASP, and data were fitted with Freundlich isotherms.

Macroporous polymeric materials find nowadays many applications in different areas of biology, chemistry, bioengineering, and biotechnology [153]. The chemical reaction that leads to gelation takes place in a frozen state which is the main phase of the process [154]. Typically, this reaction takes place at a temperature in which the solvent crystallizes, and ranges from -5 to $-2{ }^{\circ} \mathrm{C}$. Cryogels can also be functionalized attaching ligands to the polymeric matrix such as functional groups that are suitable to chelate or adsorb specific ions [153,154].

The control of the freezing rate is fundamental for the final synthesized cryogel. Slower rates can cause larger pores with higher interconnectivity, and on the contrary, mechanically 
weaker cryogels with decreased interconnectivity can be produced with faster freezing rates. This phenomenon is attributed to the supercooling of the solvent before the ice crystals begin to form, yielding small, irregular pores [154].

Macroporous cryogels were synthesized for capturing cisplatin by polymerization of methacrylic acid (MAAc) and 2-hydoroxyethylmetacrylate (HEMA), using $N, N^{\prime}$ methylenebisacrylamide (MBA) as crosslinker, and ammonium persulfate (APS) and $N, N, N^{\prime}, N^{\prime}$-tetrametyl ethylene diamine (TEMED) as an initiator and activator, respectively [125]. Cisplatin adsorption capacity of these cryogels was determined through repetitive adsorption-desorption process, the selected cryogel was added in cisplatin solution $\left(1 \mathrm{mg} \mathrm{mL}^{-1}\right)$ with a solid/liquid ratio of $10 \mathrm{mg} \mathrm{mL}^{-1}$ and held for $4 \mathrm{~h}$ at room temperature on a rocking table. The results shown that the cryogel was characterized by good stability and mechanical properties, high affinity, and high swelling ratio for cisplatin, with an adsorption capacity of up to $150 \mathrm{mg} \mathrm{g}^{-1}$ of cryogel.

The major quantity of cisplatin adsorbed was achieved with the highest MAAc content in the cryogel. This phenomenon is attributed to the complexation between the carboxylic group of the monomer and the drug [125].

Related to this technique, a recent method involving ion-imprinted sorbent of mesoporous organosilica nature has been developed [155]. Thus, $\mathrm{Pt}(\mathrm{II})$-imprinted in modified mesoporous silica materials synthesized by sol-gel approach were demonstrated efficient for remove $\mathrm{Pt}(\mathrm{II})$ ions from aqueous solutions in a wide range of $\mathrm{pH}$ with a maximum adsorption capacity of $78.7 \mathrm{mg} / \mathrm{g}$ that is 5 times higher than the non-imprinted material and is selective towards $\mathrm{Au}(\mathrm{III}), \mathrm{Pd}(\mathrm{II})$, and $\mathrm{Ru}(\mathrm{III})$.

\section{Conclusions}

In this review, studies on the environmental presence, transformation, potential ecotoxicity, and possible treatment for the removal of platinum CDs were analyzed.

The considered studies showed that in the environment the total $\mathrm{Pt}$ concentration values deriving from Pt-CD release are quite low, ranging from a few tens of ng $\mathrm{L}^{-1}$ to a few hundred $\mu \mathrm{g} \mathrm{L}^{-1}$. As consequence, the analytical determination of these drugs and their metabolites are not straightforward as they can be present at very low concentrations. In most works, the techniques of determination are based on the ICP-MS determination of total platinum and in some cases also speciation is studied.

Biological samples considered were taken from patients, hospital staff, and laboratory animals. The purpose was to monitor contamination and pharmacokinetics and therefore the release rate and speciation of the excreted $\mathrm{Pt}$ compounds. Contamination in the working environment has been shown to concern the staff in closer contact with the Pt-CD drugs and when safety protocols were revised contamination was reduced.

The knowledge of the fate of these species and their metabolites once released into the environment, and the environmental transformation products, is still limited

Several studied found adverse acute effects of the Pt-CDs on small living organisms, but at concentrations higher than the environmental ones. The effect of chronic exposure to small concentrations of Pt-CDs provided also indications of negative effects. However, several of the examined works suggested that to have a clear indication on the chronic effects further prolonged studies would be needed.

The removal of these Pt-CDs and their metabolites from the environment cannot be efficiently performed by standard WWTP. MBR and AOPs were shown to effectively eliminate organic CDs; however, this does always occur in a more limited extent for platinum compounds. Adsorption materials aimed at removing Pt CDs have been also studied; they could be a cost-effective method, which could be used to preconcentrate the compounds and then to eliminate them more efficiently. However, it should also be considered which is the most convenient location to adsorb the compounds. As excretion rates are quite slow, and given the fact that treatments are mostly in day hospital regime, it is likely that a significant fraction of Pt-CDs are released at patients' homes rather than the hospital. This has been evidenced by the studies where it was found that the total $\mathrm{Pt}$ 
found in HWW is only a fraction of the predicted one based on the quantities administered in the oncological wards. These results suggest that the specific treatment system of liquid samples to remove Pt-compounds should be placed in a convenient point along the diffusion pathway. For example, it has been suggested that directly decontaminating urine, separated upstream from the sewer system (e.g., by dedicated toilets in the hospital provided with adsorbent materials), should be an efficient process having the advantage of operating at relatively high concentrations and small treated volumes.

Author Contributions: Writing—original draft preparation, Y.R.-D.; writing—original draft preparation, review, and editing, D.V.; supervision, conceptualization, writing-review and editing, A.M.; writing and revision, M.S., M.T., D.H., M.L.-M., and M.V. All authors have read and agreed to the published version of the manuscript.

Funding: European Community's H2020 Program H2020-MSCA-RISE 2017 under the project RECOPHARMA (grant agreement \#778266). COST action 18202, “Network for Equilibria and Chemical Thermodynamics Advanced Research" (NECTAR). Program of China Scholarships Council (No. 201906450024).

Institutional Review Board Statement: Not applicable.

Informed Consent Statement: Not applicable.

Data Availability Statement: Not applicable.

Acknowledgments: This review has been developed in the framework of the European Community's H2020 Program H2020-MSCA-RISE 2017 under the project RECOPHARMA (grant agreement \#778266). D.H. acknowledges COST action 18202, "Network for Equilibria and Chemical Thermodynamics Advanced Research" (NECTAR) for supporting a STSM in Udine. D.H. acknowledges the program of China Scholarships Council (No. 201906450024).

Conflicts of Interest: The authors declare no conflict of interest.

\section{References}

1. Siegel, R.L.; Miller, K.D.; Jemal, A. Cancer statistics, 2020. CA Cancer J. Clin. 2020, 70, 7-30. [CrossRef] [PubMed]

2. WHO. IARC Cancer Tomorrow. Available online: https://gco.iarc.fr/tomorrow/en (accessed on 18 October 2021).

3. Gouveia, T.I.A.; Alves, A.; Santos, M.S.F. New insights on cytostatic drug risk assessment in aquatic environments based on measured concentrations in surface waters. Environ. Int. 2019, 133, 105236. [CrossRef]

4. Lancharro, P.M.; De Castro-Acuña Iglesias, N.; González-Barcala, F.J.; González, J.D.M. Evidence of exposure to cytostatic drugs in healthcare staff: A review of recent literature. Farm. Hosp. 2016, 40, 604-621. [CrossRef]

5. Ioannou-Ttofa, L.; Fatta-Kassinos, D. Cytostatic Drug Residues in Wastewater Treatment Plants: Sources, Removal Efficiencies and Current Challenges. In Fate and Effects of Anticancer Drugs in the Environment; Heath, E., Isidori, M., Kosjek, T., Filipič, M., Eds.; Springer International Publishing: Cham, Switzerland, 2020; pp. 103-138.

6. Zhang, J.; Chang, V.W.C.; Giannis, A.; Wang, J.-Y. Removal of cytostatic drugs from aquatic environment: A review. Sci. Total Environ. 2013, 445-446, 281-298. [CrossRef] [PubMed]

7. Toolaram, A.P.; Kümmerer, K.; Schneider, M. Environmental risk assessment of anti-cancer drugs and their transformation products: A focus on their genotoxicity characterization-state of knowledge and short comings. Mutat. Res. Mutat. Res. 2014, 760, 18-35. [CrossRef]

8. Kosjek, T.; Negreira, N.; Heath, E.; López de Alda, M.; Barceló, D. Aerobic activated sludge transformation of vincristine and identification of the transformation products. Sci. Total Environ. 2018, 610-611, 892-904. [CrossRef]

9. Booker, V.; Halsall, C.; Llewellyn, N.; Johnson, A.; Williams, R. Prioritising anticancer drugs for environmental monitoring and risk assessment purposes. Sci. Total Environ. 2014, 473-474, 159-170. [CrossRef]

10. Jureczko, M.; Kalka, J. Cytostatic pharmaceuticals as water contaminants. Eur. J. Pharmacol. 2020, 866, 172816. [CrossRef]

11. Mitra, R.; Goddard, R.; Pörschke, K.R. 9,9-Difluorobispidine Analogues of Cisplatin, Carboplatin, and Oxaliplatin. Inorg. Chem. 2017, 56, 6712-6724. [CrossRef]

12. Dasari, S.; Tchounwou, B.P. Cisplatin in cancer therapy: Molecular mechanisms of action. Eur. J. Pharmacol. 2014, 740, 364-378. [CrossRef] [PubMed]

13. Wheate, N.J.; Walker, S.; Craig, G.E.; Oun, R. The status of platinum anticancer drugs in the clinic and in clinical trials. Dalt. Trans. 2010, 39, 8113-8127. [CrossRef] [PubMed]

14. Johnstone, T.C.; Suntharalingam, K.; Lippard, S.J. The Next Generation of Platinum Drugs: Targeted Pt (II) Agents, Nanoparticle Delivery, and Pt (IV) Prodrugs. Chem. Rev. 2016, 116, 3436-3486. [CrossRef] [PubMed] 
15. Johnstone, T.C.; Suntharalingam, K.; Lippard, S.J. Third row transition metals for the treatment of cancer. Philos. Trans. R. Soc. A Math. Phys. Eng. Sci. 2015, 373. [CrossRef] [PubMed]

16. Franquet-Griell, H.; Gómez-Canela, C.; Ventura, F.; Lacorte, S. Predicting concentrations of cytostatic drugs in sewage effluents and surface waters of Catalonia (NE Spain). Environ. Res. 2015, 138, 161-172. [CrossRef] [PubMed]

17. Johnson, A.C.; Oldenkamp, R.; Dumont, E.; Sumpter, J.P. Predicting concentrations of the cytostatic drugs cyclophosphamide, carboplatin, 5-fluorouracil, and capecitabine throughout the sewage effluents and surface waters of europe. Environ. Toxicol. Chem. 2013, 32, 1954-1961. [CrossRef]

18. Valcárcel, Y.; González Alonso, S.; Rodríguez-Gil, J.L.; Gil, A.; Catalá, M. Detection of pharmaceutically active compounds in the rivers and tap water of the Madrid Region (Spain) and potential ecotoxicological risk. Chemosphere 2011, 84, 1336-1348. [CrossRef]

19. Queirós, V.; Azeiteiro, U.M.; Soares, A.M.V.M.; Freitas, R. The antineoplastic drugs cyclophosphamide and cisplatin in the aquatic environment-Review. J. Hazard. Mater. 2021, 412, 125028. [CrossRef]

20. Tripathi, A.K.; David, A.; Govil, T.; Rauniyar, S.; Rathinam, N.K.; Goh, K.M.; Sani, R.K. Environmental Remediation of Antineoplastic Drugs: Present Status, Challenges, and Future Directions. Processes 2020, 8, 747. [CrossRef]

21. Franquet-Griell, H.; Cornadó, D.; Caixach, J.; Ventura, F.; Lacorte, S. Determination of cytostatic drugs in Besòs River (NE Spain) and comparison with predicted environmental concentrations. Environ. Sci. Pollut. Res. 2017, 24, 6492-6503. [CrossRef]

22. Santos, M.S.F.; Franquet-Griell, H.; Lacorte, S.; Madeira, L.M.; Alves, A. Anticancer drugs in Portuguese surface watersEstimation of concentrations and identification of potentially priority drugs. Chemosphere 2017, 184, 1250-1260. [CrossRef] [PubMed]

23. Martín, J.; Camacho-Muñoz, D.; Santos, J.L.; Aparicio, I.; Alonso, E. Occurrence and ecotoxicological risk assessment of 14 cytostatic drugs in wastewater. Water. Air. Soil Pollut. 2014, 225, 1896. [CrossRef]

24. Franquet-Griell, H.; Pueyo, V.; Silva, J.; Orera, V.M.; Lacorte, S. Development of a macroporous ceramic passive sampler for the monitoring of cytostatic drugs in water. Chemosphere 2017, 182, 681-690. [CrossRef] [PubMed]

25. Quadra, G.R.; Oliveira de Souza, H.; Costa, R.d.S.; Fernandez, M.A.d.S. Do pharmaceuticals reach and affect the aquatic ecosystems in Brazil? A critical review of current studies in a developing country. Environ. Sci. Pollut. Res. 2017, 24, 1200-1218. [CrossRef]

26. Rosenberg, B.; Van Camp, L.; Krigas, T. Inhibition of Cell Division in Escherichia Coli by Electrolysis Products from a Platimun Electrode. Nature 1965, 205, 698-699. [CrossRef] [PubMed]

27. Rosenberg, B.; Van Camp, L.; Trosko, J.E.; Mansout, V.H. Platinum Compounds: A New Class of Potente Antitumour Agents. Nature 1969, 222, 385-386. [CrossRef]

28. Kelland, L. The resurgence of platinum-based cancer chemotherapy. Nat. Rev. Cancer 2007, 7, 573-584. [CrossRef]

29. Rottenberg, S.; Disler, C.; Perego, P. The rediscovery of platinum-based cancer therapy. Nat. Rev. Cancer 2021, 21, 37-50. [CrossRef]

30. Berners-Price, S.J.; Appleton, T.G. The Chemistry of Cisplatin in Aqueous Solution. In Platinum-Based Drugs in Cancer Therapy; Kelland, L.R., Farrell, N.P., Eds.; Humana Press: Totowa, NJ, USA, 2000; pp. 3-35.

31. Melchior, A.; Sánchez Marcos, E.; Pappalardo, R.R.; Martínez, J.M. Comparative study of the hydrolysis of a third- and a first-generation platinum anticancer complexes. Theor. Chem. Acc. 2011, 128, 627-638. [CrossRef]

32. Veclani, D.; Tolazzi, M.; Melchior, A. Molecular interpretation of pharmaceuticals' adsorption on carbon nanomaterials: Theory meets experiments. Processes 2020, 8, 642. [CrossRef]

33. Wang, D.; Lippard, S.J. Cellular processing of platinum anticancer drugs. Nat. Rev. 2005, 4, 307-320. [CrossRef]

34. Miller, S.E.; House, D.A. The hydrolysis products of cis-diamminedichloroplatinum(II). I. The kinetics of formation and anation of the cis-diammine(aqua)chloroplatinum(II) cation in acidic aqueous solution. Inorg. Chim. Acta 1989, 161, 131-137. [CrossRef]

35. Miller, S.E.; House, D.A. The hydrolysis products of cis-dichlorodiammineplatinum(II) 2 . The kinetics of formation and anation of the cis-diamminedi(aqua)platinum(II) cation. Inorg. Chim. Acta 1989, 166, 189-197. [CrossRef]

36. Miller, S.E.; House, D.A. The hydrolysis products of cis-diamminedichloroplatinum(II) 5 . The anation kinetics of cis$\mathrm{Pt}(\mathrm{X})(\mathrm{NH} 3) 2(\mathrm{OH} 2)+(\mathrm{X}=\mathrm{Cl}, \mathrm{OH})$ with glycine, monohydrogen malonate and chloride. Inorg. Chim. Acta 1991, 187, 125-132. [CrossRef]

37. Ahmad, S. Kinetic aspects of platinum anticancer agents. Polyhedron 2017, 138, 109-124. [CrossRef]

38. Credendino, R.; Minenkov, Y.; Liguori, D.; Piemontesi, F.; Melchior, A.; Morini, G.; Tolazzi, M.; Cavallo, L. Accurate experimental and theoretical enthalpies of association of TiCl4 with typical Lewis bases used in heterogeneous Ziegler-Natta catalysis. Phys. Chem. Chem. Phys. 2017, 19, 26996-27006. [CrossRef]

39. Veclani, D.; Tolazzi, M.; Cerón-Carrasco, J.P.; Melchior, A. Intercalation Ability of Novel Monofunctional Platinum Anticancer Drugs: A Key Step in Their Biological Action. J. Chem. Inf. Model. 2021, 61, 4391-4399. [CrossRef]

40. Dell'Anna, M.M.; Censi, V.; Carrozzini, B.; Caliandro, R.; Denora, N.; Franco, M.; Veclani, D.; Melchior, A.; Tolazzi, M.; Mastrorilli, P. Triphenylphosphane Pt(II) complexes containing biologically active natural polyphenols: Synthesis, crystal structure, molecular modeling and cytotoxic studies. J. Inorg. Biochem. 2016, 163, 346-361. [CrossRef] [PubMed]

41. Hann, S.; Koellensperger, G.; Stefánka, Z.; Stingeder, G.; Fürhacker, M.; Buchberger, W.; Mader, R.M. Application of HPLC-ICP-MS to speciation of cisplatin and its degradation products in water containing different chloride concentrations and in human urine. J. Anal. At. Spectrom. 2003, 18, 1391-1395. [CrossRef]

42. Boyd, L.; Muggia, F. Carboplatin/Paclitaxel Induction in Ovarian Cancer: The Finer Points. Oncology 2018, 32, $422-424$. 
43. Gridelli, C.; Chen, T.; Ko, A.; O’Brien, M.E.; Ong, T.J.; Socinski, M.A.; Postmus, P.E. Nab-paclitaxel/carboplatin in elderly patients with advanced squamous non-small cell lung cancer: A retrospective analysis of a phase iii trial. Drug Des. Devel. Ther. 2018, 12, 1445-1451. [CrossRef]

44. Narveson, L.; Kathol, E.; Rockey, M.; Henry, D.; Grauer, D.; Neupane, P. Evaluation of Weekly Paclitaxel, Carboplatin, and Cetuximab in Head and Neck Cancer Patients With Incurable Disease. Int. J. Radiat. Oncol. 2016, 94, 933-934. [CrossRef]

45. Alexander, C.; Nithyakumar, A.; Paul, M.W.B.; Arockia Samy, N. Platinum(II) complexes of imidazophenanthroline-based polypyridine ligands as potential anticancer agents: Synthesis, characterization, in vitro cytotoxicity studies and a comparative ab initio, and DFT studies with cisplatin, carboplatin, and oxaliplatin. J. Biol. Inorg. Chem. 2018, 23, 833-848. [CrossRef]

46. Riddell, I.A. Cisplatin and Oxaliplatin: Our Current Understanding of Their Actions. Met. Ions Life Sci. 2018, 18. [CrossRef]

47. Rogers, B.B.; Cuddahy, T.; Briscella, C.; Ross, N.; Olszanski, A.J.; Denlinger, C.S. Oxaliplatin: Detection and management of hypersensitivity reactions. Clin. J. Oncol. Nurs. 2019, 23, 68-75. [CrossRef]

48. Lenz, K.; Hann, S.; Koellensperger, G.; Stefanka, Z.; Stingeder, G.; Weissenbacher, N.; Mahnik, S.N.; Fuerhacker, M. Presence of cancerostatic platinum compounds in hospital wastewater and possible elimination by adsorption to activated sludge. Sci. Total Environ. 2005, 345, 141-152. [CrossRef]

49. Liu, X.; Zhang, J.; Yin, J.; Duan, H.; Wu, Y.; Shao, B. Analysis of hormone antagonists in clinical and municipal wastewater by isotopic dilution liquid chromatography tandem mass spectrometry. Anal. Bioanal. Chem. 2010, 396, 2977-2985. [CrossRef]

50. Kümmerer, K.; Helmers, E.; Hubner, P.; Mascart, G.; Milandri, M.; Reinthaler, F.; Zwakenberg, M. European hospitals as a source for platinum in the environment in comparison with other sources. Sci. Total Environ. 1999, 225, 155-165. [CrossRef]

51. Kümmerer, K. Drugs in the environment: Emission of drugs, diagnostic aids and disinfectants into wastewater by hospitals in relation to other sources-A review. Chemosphere 2001, 45, 957-969. [CrossRef]

52. Johnson, A.C.; Jürgens, M.D.; Williams, R.J.; Kümmerer, K.; Kortenkamp, A.; Sumpter, J.P. Do cytotoxic chemotherapy drugs discharged into rivers pose a risk to the environment and human health? An overview and UK case study. J. Hydrol. 2008, 348, 167-175. [CrossRef]

53. Lenz, K.; Koellensperger, G.; Hann, S.; Weissenbacher, N.; Mahnik, S.N.; Fuerhacker, M. Fate of cancerostatic platinum compounds in biological wastewater treatment of hospital effluents. Chemosphere 2007, 69, 1765-1774. [CrossRef]

54. Vyas, N.; Turner, A.; Sewell, G. Platinum-based anticancer drugs in waste waters of a major UK hospital and predicted concentrations in recipient surface waters. Sci. Total Environ. 2014, 493, 324-329. [CrossRef]

55. Isidori, M.; Lavorgna, M.; Russo, C.; Kundi, M.; Žegura, B.; Novak, M.; Filipič, M.; Mišík, M.; Knasmueller, S.; de Alda, M.L.; et al. Chemical and toxicological characterisation of anticancer drugs in hospital and municipal wastewaters from Slovenia and Spain. Environ. Pollut. 2016, 219, 275-287. [CrossRef]

56. Besse, J.-P.; Latour, J.-F.; Garric, J. Anticancer drugs in surface waters: What can we say about the occurrence and environmental significance of cytotoxic, cytostatic and endocrine therapy drugs? Environ. Int. 2012, 39, 73-86. [CrossRef]

57. Ghafuria, Y.; Yunesian, M.; Nabizadeh, R.; Mesdaghinia, A.; Dehghani, M.H.; Alimohammadi, M. Environmental risk assessment of platinum cytotoxic drugs: A focus on toxicity characterization of hospital effluents. Int. J. Environ. Sci. Technol. 2018, 15, 1983-1990. [CrossRef]

58. Mukherjee, S.; Mehta, D.; Dhangar, K.; Kumar, M. Environmental fate, distribution and state-of-the-art removal of antineoplastic drugs: A comprehensive insight. Chem. Eng. J. 2021, 407, 127184. [CrossRef]

59. da Silva, R.F.; de Lima Moura, L.; Gavião, L.O.; Brito Alves Lima, G.; Dausacker Bidone, E. Local environmental risk assessment of anticancer drugs in a developing country. Hum. Ecol. Risk Assess. Int. J. 2020, 26, 2142-2161. [CrossRef]

60. Santana-Viera, S.; Montesdeoca-Esponda, S.; Sosa-Ferrera, Z.; Santana-Rodríguez, J.J. Analytical Methodologies for the Determination of Cytostatic Compounds in Environmental Matrices. In Fate and Effects of Anticancer Drugs in the Environment; Heath, E., Isidori, M., Kosjek, T., Filipič, M., Eds.; Springer International Publishing: Cham, Switzerland, 2020; pp. 165-195, ISBN 978-3-030-21048-9.

61. Kizu, R.; Yamamoto, T.; Yokoyama, T.; Tanaka, M.; Miyazaki, M. A Sensitive Postcolumn Derivatization/UV Detection System for HPLC Determination of Antitumor Divalent and Quadrivalent Platinum Complexes. Chem. Pharm. Bull. 1995, 43, 108-114. [CrossRef]

62. Burns, R.B.; Embree, L. Validation of high-performance liquid chromatographic assay methods for the analysis of carboplatin in plasma ultrafiltrate. J. Chromatogr. B Biomed. Sci. Appl. 2000, 744, 367-376. [CrossRef]

63. Koellensperger, G.; Hann, S. Ultra-fast HPLC-ICP-MS analysis of oxaliplatin in patient urine. Anal. Bioanal. Chem. 2010, 397, 401-406. [CrossRef] [PubMed]

64. Koellensperger, G.; Stefanka, Z.; Meelich, K.; Galanski, M.; Keppler, B.K.; Stingeder, G.; Hann, S. Species specific IDMS for accurate quantification of carboplatin in urine by LC-ESI-TOFMS and LC-ICP-QMS. J. Anal. At. Spectrom. 2008, 23, 29-36. [CrossRef]

65. Shaik, A.N.; Altomare, D.A.; Lesko, L.J.; Trame, M.N. Development and validation of a LC-MS/MS assay for quantification of cisplatin in rat plasma and urine. J. Chromatogr. B Anal. Technol. Biomed. Life Sci. 2017, 1046, 243-249. [CrossRef]

66. da Costa, A.C.; Vieira, M.A.; Luna, A.S.; de Campos, R.C. Determination of platinum originated from antitumoral drugs in human urine by atomic absorption spectrometric methods. Talanta 2010, 82, 1647-1653. [CrossRef] [PubMed] 
67. Martinčič, A.; Cemazar, M.; Sersa, G.; Kovač, V.; Milačič, R.; Ščančar, J. A novel method for speciation of Pt in human serum incubated with cisplatin, oxaliplatin and carboplatin by conjoint liquid chromatography on monolithic disks with UV and ICP-MS detection. Talanta 2013, 116, 141-148. [CrossRef] [PubMed]

68. Zhang, T.; Cai, S.; Forrest, W.C.; Mohr, E.; Yang, Q.; Forrest, M.L. Development and Validation of an Inductively Coupled Plasma Mass Spectrometry (ICP-MS) Method for Quantitative Analysis of Platinum in Plasma, Urine, and Tissues. Appl. Spectrosc. 2016, 70, 1529-1536. [CrossRef] [PubMed]

69. Zachariadis, G.A.; Misopoulou, O.E. Determination of Cisplatin and Carboplatin Anticancer Drugs by Non-suppressed Ion Chromatography with an Inductively Coupled Plasma Atomic Emission Detector. Anal. Lett. 2018, 51, 1060-1070. [CrossRef]

70. Lemoine, L.; Thijssen, E.; Noben, J.-P.; Adriaensens, P.; Carleer, R.; Speeten, K. Van der A validated inductively coupled plasma mass spectrometry (ICP-MS) method for the quantification of total platinum content in plasma, plasma ultrafiltrate, urine and peritoneal fluid. J. Pharm. Biomed. Anal. 2018, 152, 39-46. [CrossRef] [PubMed]

71. Folens, K.; Mortier, S.T.F.C.; Baeten, J.; Couvreur, K.; Michelet, R.; Gernaey, K.V.; De Beer, T.; Du Laing, G.; Nopens, I. Modelling and sensitivity analysis of urinary platinum excretion in anticancer chemotherapy for the recovery of platinum. Sustain. Chem. Pharm. 2016, 4, 46-56. [CrossRef]

72. Wu, Y.; Lai, R.Y. Tunable Signal-Off and Signal-On Electrochemical Cisplatin Sensor. Anal. Chem. 2017, 89, 9984-9989. [CrossRef]

73. Petrlova, J.; Potesil, D.; Zehnalek, J.; Sures, B.; Adam, V.; Trnkova, L.; Kizek, R. Cisplatin electrochemical biosensor. Electrochim. Acta 2006, 51, 5169-5173. [CrossRef]

74. Volder, M.F.L.D.; Tawfick, S.H.; Baughman, R.H.; Hart, A.J. Carbon Nanotubes: Present and Future Commercial Applications. Science 2013, 339, 535-539. [CrossRef]

75. Suvarnaphaet, P.; Pechprasarn, S. Graphene-Based Materials for Biosensors: A Review. Sensors 2017, 17, 2161. [CrossRef] [PubMed]

76. Gholivand, M.B.; Ahmadi, E.; Mavaei, M. A novel voltammetric sensor based on graphene quantum dots-thionine/nano-porous glassy carbon electrode for detection of cisplatin as an anti-cancer drug. Sens. Actuators B Chem. 2019, 299, 126975. [CrossRef]

77. Materon, E.M.; Wong, A.; Klein, S.I.; Liu, J.; Sotomayor, M.D.P.T. Multi-walled carbon nanotubes modified screen-printed electrodes for cisplatin detection. Electrochim. Acta 2015, 158, 271-276. [CrossRef]

78. Mitchell, L.; Shen, C.; Timmins, H.C.; Park, S.B.; New, E.J. A Versatile Fluorescent Sensor Array for Platinum Anticancer Drug Detection in Biological Fluids. ACS Sens. 2021, 6, 1261-1269. [CrossRef]

79. Lenz, K.; Mahnik, S.N.; Weissenbacher, N.; Mader, R.M.; Krenn, P.; Hann, S.; Koellensperger, G.; Uhl, M.; Knasmüller, S.; Ferk, F.; et al. Monitoring, removal and risk assessment of cytostatic drugs in hospital wastewater. Water Sci. Technol. 2007, 56, 141-149. [CrossRef]

80. Ferrando-Climent, L.; Rodriguez-Mozaz, S.; Barceló, D. Development of a UPLC-MS/MS method for the determination of ten anticancer drugs in hospital and urban wastewaters, and its application for the screening of human metabolites assisted by information-dependent acquisition tool (IDA) in sewage samples. Anal. Bioanal. Chem. 2013, 405, 5937-5952. [CrossRef] [PubMed]

81. Santana-Viera, S.; Padrón, M.E.T.; Sosa-Ferrera, Z.; Santana-Rodríguez, J.J. Quantification of cytostatic platinum compounds in wastewater by inductively coupled plasma mass spectrometry after ion exchange extraction. Microchem. J. 2020, 157, 104862. [CrossRef]

82. Jadon, N.; Jain, R.; Sharma, S.; Singh, K. Recent trends in electrochemical sensors for multianalyte detection-A review. Talanta 2016, 161, 894-916. [CrossRef]

83. Kominkova, M.; Heger, Z.; Zitka, O.; Kynicky, J.; Pohanka, M.; Beklova, M.; Adam, V.; Kizek, R. Flow injection analysis with electrochemical detection for rapid identification of platinum-based cytostatics and platinum chlorides in water. Int. J. Environ. Res. Public Health 2014, 11, 1715-1724. [CrossRef] [PubMed]

84. Ghafuria, Y.; Yunesian, M.; Nabizadeh, R.; Mesdaghinia, A.; Dehghani, M.H.; Alimohammadi, M. Platinum cytotoxic drugs in the municipal wastewater and drinking water, a validation method and health risk assessment. Hum. Ecol. Risk Assess. 2018, 24, 784-796. [CrossRef]

85. Alimohammadi, M.; Asadi-Ghalhari, M.; Ghafuri, Y. Development of an analytical method for determination of carboplatin and oxaliplatin in resource water, prediction and environmental risk assessment. J. Environ. Treat. Tech. 2020, 8, 1168-1175.

86. Hann, S.; Stefánka, Z.; Lenz, K.; Stingeder, G. Novel separation method for highly sensitive speciation of cancerostatic platinum compounds by HPLC-ICP-MS. Anal. Bioanal. Chem. 2005, 381, 405-412. [CrossRef]

87. Kato, R.; Sato, T.; Kanamori, M.; Miyake, M.; Fujimoto, A.; Ogawa, K.; Kobata, D.; Fujikawa, T.; Wada, Y.; Mitsuishi, R.; et al. A novel analytical method of cisplatin using the HPLC with a naphthylethyl group bonded with silica gel ( $\pi$ NAP) column. Biol. Pharm. Bull. 2017, 40, 290-296. [CrossRef]

88. Nygren, O.; Lundgren, C. Determination of platinum in workroom air and in blood and urine from nursing staff attending patients receiving cisplatin chemotherapy. Int. Arch. Occup. Environ. Health 1997, 70, 209-214. [CrossRef]

89. Schreiber, C.; Radon, K.; Pethran, A.; Schierl, R.; Hauff, K.; Grimm, C.-H.; Boos, K.-S.; Nowak, D. Uptake of antineoplastic agents in pharmacy personnel. Part II: Study of work-related risk factors. Int. Arch. Occup. Environ. Health 2003, 76, 11-16. [CrossRef]

90. Raghavan, R.; Burchett, M.; Loffredo, D.; Mulligan, J.A. Low-Level (PPB)Determination of Cisplatin in Cleaning Validation (Rinse Water) Samples. II. A High-Performance Liquid Chromatogrphic Method. Drug Dev. Ind. Pharm. 2000, 26, 429-440. [CrossRef] [PubMed] 
91. Hori, A.; Shimura, M.; Iida, Y.; Yamada, K.; Nohara, K.; Ichinose, T.; Yamashita, A.; Shirataki, J.; Hagiwara, S. Occupational exposure of platinum-based anti-cancer drugs: Five-year monitoring of hair and environmental samples in a single hospital. $J$. Occup. Med. Toxicol. 2020, 15, 29. [CrossRef]

92. Jeronimo, M.; Colombo, M.; Astrakianakis, G.; Hon, C.-Y. A surface wipe sampling and LC-MS/MS method for the simultaneous detection of six antineoplastic drugs commonly handled by healthcare workers. Anal. Bioanal. Chem. 2015, 407, 7083-7092. [CrossRef] [PubMed]

93. Böhlandt, A.; Sverdel, Y.; Schierl, R. Antineoplastic drug residues inside homes of chemotherapy patients. Int. J. Hyg. Environ. Health 2017, 220, 757-765. [CrossRef]

94. Goykhman, N.; Dror, I.; Berkowitz, B. Transport of platinum-based pharmaceuticals in water-saturated sand and natural soil: Carboplatin and cisplatin species. Chemosphere 2019, 219, 390-399. [CrossRef]

95. Curis, E.; Provost, K.; Nicolis, I.; Bouvet, D.; Bénazeth, S.; Crauste-Manciet, S.; Brion, F.; Brossard, D. Carboplatin decomposition in aqueous solution with chloride ions monitored by X-ray absorption spectroscopy. New J. Chem. 2000, 24, 1003-1008. [CrossRef]

96. Myers, A.L.; Zhang, Y.P.; Kawedia, J.D.; Trinh, V.A.; Tran, H.; Smith, J.A.; Kramer, M.A. Stability study of carboplatin infusion solutions in $0.9 \%$ sodium chloride in polyvinyl chloride bags. J. Oncol. Pharm. Pract. 2016, 22, 31-36. [CrossRef]

97. Di Pasqua, A.J.; Goodisman, J.; Dabrowiak, J.C. Understanding how the platinum anticancer drug carboplatin works: From the bottle to the cell. Inorg. Chim. Acta 2012, 389, 29-35. [CrossRef]

98. Goykhman, N.; Dror, I.; Berkowitz, B. Transport of oxaliplatin species in water-saturated natural soil. Chemosphere 2018, 208, 829-837. [CrossRef]

99. Wormington, A.M.; De María, M.; Kurita, H.G.; Bisesi, J.H.; Denslow, N.D.; Martyniuk, C.J. Antineoplastic Agents: Environmental Prevalence and Adverse Outcomes in Aquatic Organisms. Environ. Toxicol. Chem. 2020, 39, 967-985. [CrossRef]

100. Nassour, C.; Nabhani-Gebara, S.; Barton, S.J.; Barker, J. Aquatic ecotoxicology of anticancer drugs: A systematic review. Sci. Total Environ. 2021, 800, 149598. [CrossRef]

101. Brezovšek, P.; Eleršek, T.; Filipič, M. Toxicities of four anti-neoplastic drugs and their binary mixtures tested on the green alga Pseudokirchneriella subcapitata and the cyanobacterium Synechococcus leopoliensis. Water Res. 2014, 52, 168-177. [CrossRef]

102. Supalkova, V.; Beklova, M.; Baloun, J.; Singer, C.; Sures, B.; Adam, V.; Huska, D.; Pikula, J.; Rauscherova, L.; Havel, L.; et al. Affecting of aquatic vascular plant Lemna minor by cisplatin revealed by voltammetry. Bioelectrochemistry 2008, 72, 59-65. [CrossRef] [PubMed]

103. Kajander, V.; Sewell, G.; Turner, A. Bioaccumulation and toxicity of oxaliplatin in fresh water: A study with Lemna minor. Environ. Adv. 2021, 3, 100030. [CrossRef]

104. Parrella, A.; Lavorgna, M.; Criscuolo, E.; Russo, C.; Fiumano, V.; Isidori, M. Acute and chronic toxicity of six anticancer drugs on rotifers and crustaceans. Chemosphere 2014, 115, 59-66. [CrossRef]

105. Hung, G.-Y.; Wu, C.-L.; Chou, Y.-L.; Chien, C.-T.; Horng, J.-L.; Lin, L.-Y. Cisplatin exposure impairs ionocytes and hair cells in the skin of zebrafish embryos. Aquat. Toxicol. 2019, 209, 168-177. [CrossRef] [PubMed]

106. Easton, C.; Turner, A.; Sewell, G. An evaluation of the toxicity and bioaccumulation of cisplatin in the marine environment using the macroalga, Ulva lactuca. Environ. Pollut. 2011, 159, 3504-3508. [CrossRef]

107. Mišík, M.; Filipic, M.; Nersesyan, A.; Kundi, M.; Isidori, M.; Knasmueller, S. Environmental risk assessment of widely used anticancer drugs (5-fluorouracil, cisplatin, etoposide, imatinib mesylate). Water Res. 2019, 164, 114953. [CrossRef] [PubMed]

108. Russo, C.; Graziani, V.; Lavorgna, M.; D’Abrosca, B.; Piscitelli, C.; Fiorentino, A.; Scognamiglio, M.; Isidori, M. Lymphocytes exposed to vegetables grown in waters contaminated by anticancer drugs: Metabolome alterations and genotoxic risks for human health. Mutat. Res.-Genet. Toxicol. Environ. Mutagen. 2019, 842, 125-131. [CrossRef] [PubMed]

109. Dehghanpour, S.; Pourzamani, H.R.; Amin, M.M.; Ebrahimpour, K. Evaluation of toxic effects of platinum-based antineoplastic drugs (cisplatin, carboplatin and oxaliplatin) on green alga Chlorella vulgaris. Aquat. Toxicol. 2020, 223, 105495. [CrossRef]

110. Bownik, A.; Ślaska, B.; Dudka, J. Cisplatin affects locomotor activity and physiological endpoints of Daphnia magna. J. Hazard. Mater. 2020, 384, 1-8. [CrossRef]

111. Fonseca, T.G.; Morais, M.B.; Rocha, T.; Abessa, D.M.S.; Aureliano, M.; Bebianno, M.J. Ecotoxicological assessment of the anticancer drug cisplatin in the polychaete Nereis diversicolor. Sci. Total Environ. 2017, 575, 162-172. [CrossRef]

112. Kolarević, S.; Gačić, Z.; Kostić, J.; Sunjog, K.; Kračun-Kolarević, M.; Paunović, M.; Knežević-Vukčević, J.; Vuković-Gačić, B. Impact of Common Cytostatics on DNA Damage in Freshwater Mussels Unio pictorum and Unio tumidus. CLEAN Soil Air Water 2016, 44, 1471-1476. [CrossRef]

113. Trombini, C.; Garcia da Fonseca, T.; Morais, M.; Rocha, T.L.; Blasco, J.; Bebianno, M.J. Toxic effects of cisplatin cytostatic drug in mussel Mytilus galloprovincialis. Mar. Environ. Res. 2016, 119, 12-21. [CrossRef]

114. Mello, L.C.; da Fonseca, T.G.; Denis Moledode de Souza, A. Ecotoxicological assessment of chemotherapeutic agents using toxicity tests with embryos of Mellita quinquiesperforata. Mar. Pollut. Bull. 2020, 159, 111493. [CrossRef]

115. Grzesiuk, M.; Bednarska, A.; Mielecki, D.; Garbicz, D.; Marcinkowski, M.; Pilžys, T.; Malinowska, A.; Świderska, B.; Grzesiuk, E. Anticancer agents found in environment affect Daphnia at population, individual and molecular levels. Aquat. Toxicol. 2019, 215, 105288. [CrossRef]

116. Nath, J.; Dror, I.; Berkowitz, B. Effect of nanoplastics on the transport of platinum-based pharmaceuticals in water-saturated natural soil and their effect on a soil microbial community. Environ. Sci. Nano 2020, 7, 3178-3188. [CrossRef] 
117. Siedlecka, E.M. Removal of Cytostatic Drugs from Water and Wastewater: Progress in the Development of Advanced Treatment Methods. In Fate and Effects of Anticancer Drugs in the Environment; Healt, E., Isidor, M., Kosjek, T., Filipič, M., Eds.; Springer: Berlin/Heidelberg, Germany, 2020.

118. Delgado, L.F.; Faucet-Marquis, V.; Pfohl-Leszkowicz, A.; Dorandeu, C.; Marion, B.; Schetrite, S.; Albasi, C. Cytotoxicity micropollutant removal in a crossflow membrane bioreactor. Bioresour. Technol. 2011, 102, 4395-4401. [CrossRef]

119. Köhler, C.; Venditti, S.; Igos, E.; Klepiszewski, K.; Benetto, E.; Cornelissen, A. Elimination of pharmaceutical residues in biologically pre-treated hospital wastewater using advanced UV irradiation technology: A comparative assessment. J. Hazard. Mater. 2012, 239-240, 70-77. [CrossRef]

120. Kazner, C.; Lehnberg, K.; Kovalova, L.; Wintgens, T.; Melin, T.; Hollender, J.; Dott, W. Removal of endocrine disruptors and cytostatics from effluent by nanofiltration in combination with adsorption on powdered activated carbon. Water Sci. Technol. 2008, 58, 1699-1706. [CrossRef]

121. Ahmadijokani, F.; Tajahmadi, S.; Rezakazemi, M.; Sehat, A.A.; Molavi, H.; Aminabhavi, T.M.; Arjmand, M. Aluminum-based metal-organic frameworks for adsorptive removal of anti-cancer (methotrexate) drug from aqueous solutions. J. Environ. Manag. 2021, 277, 111448. [CrossRef]

122. Hirose, J.; Kondo, F.; Nakano, T.; Kobayashi, T.; Hiro, N.; Ando, Y.; Takenaka, H.; Sano, K. Inactivation of antineoplastics in clinical wastewater by electrolysis. Chemosphere 2005, 60, 1018-1024. [CrossRef] [PubMed]

123. Hernández, C.; Ramos, Y.; Fernández, L.A.; Ledea, O.; Bataller, M.; Véliz, E.; Besada, V.; Rosado, A. Ozonation of cisplatin in aqueous solution at pH 9. Ozone Sci. Eng. 2008, 30, 189-196. [CrossRef]

124. Janssens, R.; Mandal, M.K.; Dubey, K.K.; Luis, P. Slurry photocatalytic membrane reactor technology for removal of pharmaceutical compounds from wastewater: Towards cytostatic drug elimination. Sci. Total Environ. 2017, 599-600, 612-626. [CrossRef] [PubMed]

125. Farías, T.; Hajizadeh, S.; Ye, L. Cryogels with high cisplatin adsorption capacity: Towards removal of cytotoxic drugs from wastewater. Sep. Purif. Technol. 2020, 235, 116203. [CrossRef]

126. Judd, S. The status of membrane bioreactor technology. Trends Biotechnol. 2008, 26, 109-116. [CrossRef]

127. Iorhemen, O.T.; Hamza, R.A.; Tay, J.H. Membrane bioreactor (Mbr) technology for wastewater treatment and reclamation: Membrane fouling. Membranes 2016, 6, 33. [CrossRef] [PubMed]

128. Lin, H.; Gao, W.; Meng, F.; Liao, B.Q.; Leung, K.T.; Zhao, L.; Chen, J.; Hong, H. Membrane bioreactors for industrial wastewater treatment: A critical review. Crit. Rev. Environ. Sci. Technol. 2012, 42, 677-740. [CrossRef]

129. Mutamim, N.S.A.; Noor, Z.Z.; Hassan, M.A.A.; Yuniarto, A.; Olsson, G. Membrane bioreactor: Applications and limitations in treating high strength industrial wastewater. Chem. Eng. J. 2013, 225, 109-119. [CrossRef]

130. Clara, M.; Kreuzinger, N.; Strenn, B.; Gans, O.; Kroiss, H. The solids retention time-A suitable design parameter to evaluate the capacity of wastewater treatment plants to remove micropollutants. Water Res. 2005, 39, 97-106. [CrossRef]

131. De Wever, H.; Weiss, S.; Reemtsma, T.; Vereecken, J.; Müller, J.; Knepper, T.; Rörden, O.; Gonzalez, S.; Barcelo, D.; Dolores Hernando, M. Comparison of sulfonated and other micropollutants removal in membrane bioreactor and conventional wastewater treatment. Water Res. 2007, 41, 935-945. [CrossRef]

132. García, L.A.F.; Lozano, O.L.; Lorenzo, E.V.; Venta, M.B.; Rodríguez, Y.R.; Castro, C.H.; Trujillo, C.G.; Torres, I.F. Review of cytostatic wastewater degradation by ozone and advanced oxidation processes: Results from cuban studies. Environ. Rev. 2020, 28, 21-31. [CrossRef]

133. Kanakaraju, D.; Glass, B.D.; Oelgemöller, M. Advanced oxidation process-mediated removal of pharmaceuticals from water: A review. J. Environ. Manag. 2018, 219, 189-207. [CrossRef] [PubMed]

134. Miklos, D.B.; Remy, C.; Jekel, M.; Linden, K.G.; Drewes, J.E.; Hübner, U. Evaluation of advanced oxidation processes for water and wastewater treatment-A critical review. Water Res. 2018, 139, 118-131. [CrossRef]

135. Mirzaei, A.; Chen, Z.; Haghighat, F.; Yerushalmi, L. Removal of pharmaceuticals from water by homo/heterogonous Fenton-type processes-A review. Chemosphere 2017, 174, 665-688. [CrossRef] [PubMed]

136. Mirzaei, A.; Chen, Z.; Haghighat, F.; Yerushalmi, L. Removal of pharmaceuticals and endocrine disrupting compounds from water by zinc oxide-based photocatalytic degradation: A review. Sustain. Cities Soc. 2016, 27, 407-418. [CrossRef]

137. Giri, R.R.; Ozaki, H.; Takayanagi, Y.; Taniguchi, S.; Takanami, R. Efficacy of ultraviolet radiation and hydrogen peroxide oxidation to eliminate large number of pharmaceutical compounds in mixed solution. Int. J. Environ. Sci. Technol. 2011, 8, 19-30. [CrossRef]

138. Prado, M.; Borea, L.; Cesaro, A.; Liu, H.; Naddeo, V.; Belgiorno, V.; Ballesteros, F. Removal of emerging contaminant and fouling control in membrane bioreactors by combined ozonation and sonolysis. Int. Biodeterior. Biodegrad. 2017, 119, 577-586. [CrossRef]

139. Kobayashi, T.; Hirose, J.; Sano, K.; Hiro, N.; Ijiri, Y.; Takiuchi, H.; Tamai, H.; Takenaka, H.; Tanaka, K.; Nakano, T. Evaluation of an electrolysis apparatus for inactivating antineoplastics in clinical wastewater. Chemosphere 2008, 72, 659-665. [CrossRef]

140. Buxton, G.V.; Greenstock, C.L.; Helman, W.P.; Ross, A.B. Critical Review of rate constants for reactions of hydrated electrons, hydrogen atoms and hydroxyl radicals $(\cdot \mathrm{OH} / \cdot \mathrm{O}-$ in Aqueous Solution. J. Phys. Chem. Ref. Data 1988, 17, 513-886. [CrossRef]

141. Patel, M.; Kumar, R.; Kishor, K.; Mlsna, T.; Pittman, C.U.; Mohan, D. Pharmaceuticals of Emerging Concern in Aquatic Systems: Chemistry, Occurrence, Effects, and Removal Methods. Chem. Rev. 2019, 119, 3510-3673. [CrossRef] [PubMed]

142. Lanas, S.G.; Valiente, M.; Aneggi, E.; Trovarelli, A.; Tolazzi, M.; Melchior, A. Efficient fluoride adsorption by mesoporous hierarchical alumina microspheres. RSC Adv. 2016, 6, 42288-42296. [CrossRef] 
143. Tao, Z.; Toms, B.; Goodisman, J.; Asefa, T. Mesoporous Silica Microparticles Enhance the Cytotoxicity of Anticancer Platinum Drugs. ACS Nano 2010, 4, 789-794. [CrossRef] [PubMed]

144. Ma, P.; Xiao, H.; Li, C.; Dai, Y.; Cheng, Z.; Hou, Z.; Lin, J. Inorganic nanocarriers for platinum drug delivery. Mater. Today 2015, 18, 554-564. [CrossRef]

145. Hilder, T.A.; Hill, J.M. Modelling the encapsulation of the anticancer drug cisplatin into carbon nanotubes. Nanotechnology 2007, 18, 275704. [CrossRef]

146. Mejri, A.; Vardanega, D.; Tangour, B.; Gharbi, T.; Picaud, F. Encapsulation into carbon nanotubes and release of anticancer cisplatin drug molecule. J. Phys. Chem. B 2015, 119, 604-611. [CrossRef] [PubMed]

147. Veclani, D.; Melchior, A. Adsorption of ciprofloxacin on carbon nanotubes: Insights from molecular dynamics simulations. J. Mol. Liq. 2020, 298. [CrossRef]

148. Melchior, A.; Lanas, S.G.; Valiente, M.; Tolazzi, M. Thermodynamics of sorption of platinum on superparamagnetic nanoparticles functionalized with mercapto groups. J. Therm. Anal. Calorim. 2018, 134, 1261-1266. [CrossRef]

149. Callari, M.; Aldrich-Wright, J.R.; de Souza, P.L.; Stenzel, M.H. Polymers with platinum drugs and other macromolecular metal complexes for cancer treatment. Prog. Polym. Sci. 2014, 39, 1614-1643. [CrossRef]

150. Solomevich, S.O.; Dmitruk, E.I.; Bychkovsky, P.M.; Nebytov, A.E.; Yurkshtovich, T.L.; Golub, N.V. Fabrication of oxidized bacterial cellulose by nitrogen dioxide in chloroform/cyclohexane as a highly loaded drug carrier for sustained release of cisplatin. Carbohydr. Polym. 2020, 248, 116745. [CrossRef] [PubMed]

151. Folens, K.; Abebe, A.; Tang, J.; Ronsse, F.; Du Laing, G. Biosorption of residual cisplatin, carboplatin and oxaliplatin antineoplastic drugs in urine after chemotherapy treatment. Environ. Chem. 2018, 15, 506-512. [CrossRef]

152. Ogata, F.; Inoue, K.; Tominaga, H.; Iwata, Y.; Ueda, A.; Tanaka, Y.; Kawasaki, N. Use of Calcined Gibbsite to Remove Cisplatin from Aqueous Solutions. J. Water Environ. Technol. 2014, 12, 13-23. [CrossRef]

153. Ertürk, G.; Mattiasson, B. Cryogels-versatile tools in bioseparation. J. Chromatogr. A 2014, 1357, 24-35. [CrossRef] [PubMed]

154. Hixon, K.R.; Lu, T.; Sell, S.A. A comprehensive review of cryogels and their roles in tissue engineering applications. Acta Biomater. 2017, 62, 29-41. [CrossRef] [PubMed]

155. Dobrzyńska, J.; Dabrowska, M.; Olchowski, R.; Zięba, E.; Dobrowolski, R. Development of a method for removal of platinum from hospital wastewater by novel ion-imprinted mesoporous organosilica. J. Environ. Chem. Eng. 2021, 9, 105302. [CrossRef] 